\title{
Lactoferrin as a Natural Immune Modulator
}

\author{
Jeffrey K. Actor ${ }^{1}{ }^{,}$, Shen-An Hwang ${ }^{1}$, and Marian L. Kruzel ${ }^{2}$ \\ ${ }^{1}$ Department of Pathology and Laboratory Medicine, University of Texas Health Science Center \\ at Houston, TX 77030 \\ 2 Department of Integrative Biology and Pharmacology, University of Texas Health Science \\ Center at Houston, TX 77030, USA
}

\begin{abstract}
Lactoferrin, an iron-binding glycoprotein, is a cell-secreted mediator that bridges innate and adaptive immune function in mammals. It is a pleiotropic molecule that directly assists in the influence of presenting cells for the development of T-helper cell polarization. The aim of this review is to provide an overview of research regarding the role of lactoferrin in maintaining immune homeostasis, in particular as a mediator of immune responses to infectious assault, trauma and injury. These findings are critically relevant in the development of both prophylactic and therapeutic interventions in humans. Understanding these particular effects of lactoferrin will provide a logical framework for determining its role in health and disease.
\end{abstract}

\section{Keywords}

Lactoferrin; innate immunity; adaptive immunity; immunomodulation; inflammation; oxidative stress; adjuvant

\section{INTRODUCTION}

Immune responses are designed to interact with the environment to protect the host against pathogenic invaders, conferring a state of health through effective elimination of infectious agents (bacteria, viruses, fungi, and parasites) and modulation of systemic responses comprising host immune surveillance. Recent research has identified lactoferrin, a member of the transferrin family of iron binding glycoproteins, as a critical component in mediation of immune response, especially for coordinated interactions between innate and adaptive components and associated responses. Engagement of innate components leads to triggering of signal pathways to promote inflammation, ensuring that invading pathogens remain in check while the specific immune response is either generated or upregulated. Lactoferrin is a key molecule involved in these processes.

The immune system protects the body from potentially harmful environmental stimuli through recognition and responding with multiple immunological reactions. Myeloid cells, including the highly phagocytic, motile polymorphonuclear neutrophils, macrophages and dendritic cells, provide a first line of defense against most pathogens. There is emerging evidence that many mediators originating from the myeloid lineage revive immune homeostasis in most insult-induced metabolic disparity [1,2]. Thus, the utility of such

\footnotetext{
*Address correspondence to this author at the UT-Houston Medical School, University of Texas, Health Science Center at Houston, Department of Pathology and Laboratory Medicine, MSB 2.214, 6431 Fannin Street; Houston, TX 77030, USA; Tel: 713-500-5344; Fax: 713-500-0730; Jeffrey.K.Actor@uth.tmc.edu.
} 
immune mediators represents a novel therapeutic approach that depends on immunopotentiation, immunosuppression, or induction of immunological tolerance. Lactoferrin is one of these mediators that naturally bridge the innate and adaptive immune functions by regulating target cell response, including those involved in oxidative stress and systemic inflammatory responses. It is also recognized as a significant contributor in regulation of antigen presentation and development of productive $\mathrm{T}$ helper cell response.

Lactoferrin is a well conserved, monomeric $80-\mathrm{kDa}$ single polypeptide chain glycoprotein of about 690 amino acid residues [3,4]. While lactoferrin is found primarily in mucosal secretions, synthesized by epithelial cells, it is also present in neutrophilic granules [5]. Lactoferrin is considered a first-line defense protein involved in protection against a multitude of microbial infections [6-8] and prevention of systemic inflammation [9-11]. While the goal of this review is to examine immune modulating activity of lactoferrin, it is important to consider that lactoferrin also exhibits direct effects on pathogens [12-15]. These include bacteriostatic and bactericidal effects, the former being a result of iron sequestration by lactoferrin and the latter dealing with lactoferrin capabilities to bind lipopolysaccharide (LPS) [16-23]. The ability of lactoferrin to bind large quantities of iron also provides protection against pathogens and their metabolites by enhancing phagocytosis and cell adherence and controlling the release of proinflammatory cytokines [24,25]. Other direct effects of lactoferrin include anti-viral [21,26-32], anti-parasitic [33-35], and antifugal [36-41] activities. Additionally, lactoferrin possesses indirect activity, often through prevention of pathogen invasion by blocking interaction with receptors used for entry on host cells [42-44].

While suppressing microbial growth, lactoferrin also exerts direct first-line defense activity through its significant impact on the development of adaptive immune responses.

Sequestration of iron by lactoferrin reduces insult-induced oxidative stress, thus altering the magnitude and specific production of cytokines [45]. Lactoferrin has a profound modulatory action on the adaptive immune system [46-48] by promoting the maturation of T-cell precursors into competent helper cells and by the differentiation of immature B-cells into efficient antigen presenting cells [49]. In addition, lactoferrin augments the delayed type hypersensitivity (DTH) response to antigens, leading to a strong induction of cell-mediated immunity in mice [50,51]. Each of these topics will be discussed in detail.

\section{LACTOFERRIN AS A MEDIATOR OF OXIDATIVE STRESS-INDUCED RESPONSES}

Lactoferrin is a primary constituent of immune homeostasis, functioning to reduce oxidative stress at the molecular level, and thus controlling excess inflammatory response. Oxidative stress occurs when the production of potentially destructive reactive oxygen species (ROS) exceeds the body's own natural antioxidant defenses and results in cellular damage. A cell is able to overcome small perturbations and regain its original state; but, severe oxidative stress can cause cell death. While moderate oxidation can trigger apoptosis, more intense stresses can cause necrosis within tissue [52-54]. There is substantial evidence that oxidative stress is a causative factor in the pathogenesis of major neurodegenerative diseases, including Parkinson's disease [55], Alzheimer's disease [56], and amyotrophic lateral sclerosis $[57,58]$, and is involved in cases of stroke, trauma, seizures [59,60], rheumatoid arthritis, fatigue, or cancer [61,62]. Also, there is ample evidence that allergic disorders, such as asthma, rhinitis, and atopic dermatitis, are mediated by oxidative stress [63]. In fact, the oxidative stress-induced immune hypersensitivity indicates a shift in immunostasis towards the Th 2 responses. The Th1/Th2 balance is responsible for coordinating the immune system and become very important during aging processes, 
including the development of autoimmune, neurodegenerative and immune hypersensitivity disorders.

Transitional metals may be considered as key factors in the oxidative stress. In particular, traces of iron can be detrimental to physiological processes under reactive oxygen conditions. Iron is crucial in modulating production of reactive oxygen species (ROS), by virtue of its ability to catalyze a two step process known as the Haber-Weiss reaction [64]. In normal physiological conditions, the production and neutralization of these reactive oxygen species largely depends on the efficiency of key enzymes, including superoxide dismutase, catalase and glutathione peroxidase. Inefficiency of these enzymes leads to overexpression of hydroxyl radical via iron-dependent Haber-Weiss reaction, and subsequent increase in lipid peroxidation. It is hypothesized that endogenous lactoferrin can prevent lipid peroxidation by virtue of iron sequestration. This may have a significant systemic implication as lipid peroxidation products, namely hydroxyalkenals, can randomly inactivate or modify functional proteins and affect vital metabolic pathways. There is substantial evidence that acute overproduction of ROS can result in pathological damage due to severe injury or death of cells in affected tissues [52].

\section{ANTI-OXIDANT PROPERTIES OF LACTOFERRIN}

Preliminary experiments in our laboratory demonstrated that lactoferrin can function as an anti-oxidant, reducing intracellular levels of ROS induced by glucose oxidize (GO). Based on this initial study it was hypothesized that lactoferrin could function to reduce oxidative stress-induced apoptosis. Apoptosis is a programmed cells death, characterized by activation of caspases. The human monocytic cell line (U937) was used to measure caspase-3 activation by lactoferrin. Cells were pre-treated with lactoferrin $(125$ or $250 \mu \mathrm{g} / \mathrm{mL})$ or Nacetyl-L-cysteine (as control; $10 \mathrm{mM}$ ), and then exposed to $\mathrm{GO}(500 \mathrm{ng} / \mathrm{mL}$; predetermined to killed cells via apoptosis in preliminary studies). Caspase-3 activity was determined by measuring the change in absorbance at $405 \mathrm{~nm}$. Indeed, lactoferrin was able to limit caspase-3 activation in apoptotic U937 cells (Fig. 1). To further test inhibition of apoptosis by lactoferrin, Annexin V-FITC staining was employed. U937 cells were treated with lactoferrin, GO, or in combination. Comparisons were made to z-DEVD-fmk (Nbenzyloxycarbonyl-Asp(OMe)-Glu(OMe) -Val-Asp(OMe)-fluoro-methylketone), a caspase-3 inhibitor control. Again, lactoferrin effectively reduced glucose oxidase-induced apoptosis (Fig. 1). There is also published confirmation that daily oral administration of lactoferrin can support the immune system response through antioxidative mechanisms [65].

\section{LACTOFERRIN AS A MEDIATOR OF SYSTEMIC INFLAMMATORY RESPONSE SYNDROME (SIRS)}

Early host defenses during septicemia and endotoxemia include a rapid rise in serum lactoferrin concentration [66]. The significance of this response is well established, although the mechanisms are not clearly understood. Systemic inflammatory response syndrome (SIRS), induced either by endotoxin or live bacteria, represents the earliest manifestation of immune function in which molecular aspects of increased ROS leads to exacerbated inflammation. There is growing evidence showing that progression of systemic inflammatory response syndrome into sepsis is due to the cellular damage and death induced by acute inflammatory responses. The cell death depends in part upon mitochondrial dysfunction, which is often characterized by increased production of reactive oxygen species (ROS), increased membrane permeability and eventual release of cell death mediators from mitochondria [67]. Extensive mitochondrial damage leads to loss of cellular ATP pools, which can be linked to necrotic cell death, to further inflammatory responses. Consequently, mitochondrial dysfunction contributes to a wide range of human pathologies including SIRS 
and sepsis. Lactoferrin is a critical component involved in mediation of this response, so as to allow controlled regulation of inflammation without rapid induction of pathological damage. The mechanism of action for lactoferrin contains multiple components for differential regulation of cellular immune responses during the development of SIRS. Both endotoxemia and bacteremia are manifested by severe clinical syndromes characterized by proinflammatory cytokine release, increased expression of adhesion molecules, and massive release of reactive oxygen species [68-70]. Vascular inflammation occurs within minutes of Gram negative bacterial infection and coincides with a burst of proinflammatory cytokines derived from activated monocytes-macrophages. There is increasing evidence that bacteremia and endotoxemia stimulate the immune system into a self-perpetuating, generalized state of hyperactivity. In particular, the systemic inflammatory response to bacterial LPS induces gut-associated lymphoid tissue to produce and liberate proinflammatory cytokines which in turn affects gut mucosal permeability. This contributes to enteric bacterial translocation to distant sites [71-74]. Recently, the LPS-induced oxidative burst was found to be of mitochondrial origin, and release of reactive oxygen species (ROS) was localized to the respiratory complex III. Importantly, lactoferrin nearly abolished LPS-induced increases in mitochondrial ROS generation and accumulation of oxidative damage to DNA. In vivo, pretreatment of experimental animals with LF significantly lowered LPS-induced mitochondrial dysfunction shown by decreased release of $\mathrm{H}_{2} \mathrm{O}_{2}$ and reduced DNA damage in the mitochondria (personal communication, $\mathrm{S}$.

Boldogh). The potential use of lactoferrin for amelioration of clinical sepsis has been an active area of research in our laboratory.

Injection of LPS into animals virtually reproduces the pathophysiologic changes induced by live bacteria, and it is considered a standard model for sepsis. Using this model, it was demonstrated that treatment of mice with lactoferrin reduced or eliminated many of the biological effects normally seen upon administration of endotoxin [75-79] (summarized in Table 1). A single dose of lactoferrin administered $1 \mathrm{~h}$ before LPS injection significantly increased survival of mice when compared with the saline-treated controls. Overall, the mortality rate was $16.7 \%$ in the lactoferrin-treated mice and $83.3 \%$ in the saline control group [61].

The protective effect of lactoferrin against bacteremia has also been demonstrated in mice $[14,80]$. We further investigated this observation in CFW mice for ability to clear bacteria from serum and tissue when treated with lactoferrin. Mice were administered a bolus dose of lactoferrin (10 mg) $1 \mathrm{~h}$ prior to challenge with enterotoxigenic Escherichia coli (E. coli 844 $078 \mathrm{~K} 80 / \mathrm{B})$ at a lethal dose $\left(2 \times 10^{8}\right.$ organisms, intravenous injection). $80 \%$ of mice treated with lactoferrin survived through 30 days, compared to $100 \%$ death by three days in mice given either saline or human serum albumin (HSA) control injections (data not shown). Levels of organisms were quantitated post injection of enterotoxigenic bacteria. Mice pretreated with lactoferrin demonstrated greater than 100 -fold reduction in organisms in circulation compared to controls (Fig. 2). E. coli was also measured in lungs, spleens, livers and kidneys. The effect was most dramatic when examining bacterial load remaining within lung tissue (Fig. 3), where there was over 1000-fold reduction in number of organisms. All tissues demonstrated decreased bacterial loads (at least 10-fold reduction in spleen, liver and kidney), when compared with phosphate buffered saline and/or HSA controls. This indicates increased killing, and not merely a difference in sequestration of organisms. Taken together, these data show that lactoferrin will protect against progression of insult-induced systemic inflammatory responses in models of SIRS and sepsis by reducing immune mediators and oxidative stress that contribute to tissue damage.

In other murine bacteremia model using E. coli (strain SM105) [81], mice were intravenous injected with approximately $1.5 \times 10^{9} \mathrm{CFU} /$ mouse, similar to models previously described 
[82]. At this dose, mice survived the infection, with high levels of circulating proinflammatory mediators and large bacterial load in tissues. Addition of lactoferrin prior to infectious challenge led to non-significant reduction in organ bacterial load in all tissues examined (data not shown). Serum cytokines were measured in the above mice just prior to sacrifice. In all cases cytokines were reduced due to pretreatment with lactoferrin. The greatest reductions were noticed in IL-6, which persisted through 4 days post infection. It was of interest to note that no concurrent changes were observed in TNF- $\alpha$ at that time, although it is speculated that decreases may have occurred if earlier times were examined (Fig. 4). A significant decrease of serum IL-12 and IL-10 cytokine levels was also observed (data not shown). Changes in intestinal tissue (jejunal section) were also examined (Fig. 5). At 4 days post infection, control mice demonstrated disruption to microvilli, with large submucosal accumulation of activated cells. The pretreatment with lactoferrin led to nearly full protection of gut associated tissue in all mice examined.

\section{LACTOFERRIN AS A POTENTIAL MODULATOR OF EVENTS DURING MRSA CHALLENGE}

Overwhelming immune responses due to Gram-positive bacterial infections can also elicit similar cascades as demonstrated above with the Gram-negative E. coli. For example, Staphylococcus aureus initiates a cytokine storm, in large part due to superantigens that trigger non-specific lymphocyte activation [83-85]. Indeed, with the advent of multi-drug resistant organisms, it is critical to develop current therapeutic approaches that include antiinflammatory and antimicrobial strategies. In particular a new threat comes from the methicillin-resistant Staphylococcus aureus (MRSA) infection, which is responsible for more deaths in the United States each year than AIDS. It is also a major cause of sepsis in patients who are disease or drug-immunosuppressed.

Pilot experiments were completed examining MRSA in a peritonitis murine model to investigate the potential for lactoferrin to mediate inflammatory responses. Lactoferrin was given prior to challenge with a lethal dose of MRSA, and mice were monitored for survival, bacteremia, and proinflammatory cytokines. Mice pre-treated with lactoferrin significantly increased host survival (75\%) compared to the control non-treated group (25\%) (Fig. 6A). Serum bacteremia showed a delay in translocation of MRSA from the injection site, peritoneal cavity, to the circulation. Of high interest, circulating cytokine levels post challenge from mice pre-treated with lactoferrin exhibited a marked decrease in IL-6, with no changes in TNF- $\alpha$ (Fig. 6C,D), similar to that observed in the above $E$. coli peritonitis experiments. These experiments point to a potential for lactoferrin to function as a therapeutic against both Gram-positive and Gram-negative organisms, by inducing moderation of proinflammatory mediators during bacterial infection.

\section{LACTOFERRIN AS A MEDIATOR BRIDGING THE INNATE AND ADAPTIVE IMMUNE RESPONSES}

The role that lactoferrin plays in regulating innate immune responses confirms its importance as a first line host defense mechanism against invading pathogens. Indeed, multiple laboratories are actively investigating the role of lactoferrin to modulate both acute and chronic inflammation $[11,45,86]$. Most intriguing is the ability of lactoferrin to induce mediators from innate immune cells that subsequently impact adaptive immune cell function.

By virtue of high affinity to iron, lactoferrin is considered an important component of nonspecific host defense system against various pathogens in humans. A high level of lactoferrin in plasma has been suggested to be a predictive indicator of sepsis-related 
morbidity and mortality [10]. Lactoferrin is also known to exert changes on leukocytes of the innate immune system, through increasing natural killer (NK) cell activity [87,88], promoting function of neutrophils by enhancing phagocytic activity and modifying production of reactive oxygen species [89-91], and activating macrophages through increasing cytokine and NO production and limiting intracellular pathogen proliferation [50,92-96]. The degranulation of neutrophils in response to inflammatory signals introduces lactoferrin into an environment that is populated with a mix of both innate leukocytes (macrophages, dendritic cells, NK cells) and adaptive immune cells (T-cells and B-cells). The discovery of lactoferrin receptors on a wide variety of immune cells, and their demonstrated capability to bind lactoferrin, [97-102], confirms the potential for this molecule to function in a manner to modulate and affect responses of both the innate and adaptive immune system.

Modulation of cytokine production from leukocyte populations by lactoferrin has been profoundly examined. Proinflammatory cytokines, TNF- $\alpha$, IL-6, and IL- $1 \beta$, can be modulated by lactoferrin, either to increase $[94,103,104]$ or decrease $[11,76,105,106]$ production dependent upon the type of insult recognized by the immune system in concert with local environmental conditions. In addition to changes in the above mentioned proinflammatory cytokines, lactoferrin can also increase in vivo and in vitro production of IL-12 [107-111], a cytokine produced by antigen presenting cells (APCs) upon encountering pathogens. IL-12, a heterodimer comprised of two subunits p40 and p35, functions to enhance production of IFN- $\gamma$, increase proliferation, and augment cytotoxic activity of lymphocytes of the innate (NK cells) and adaptive $\left(\mathrm{CD} 4^{+}\right.$and $\mathrm{CD} 8^{+} \mathrm{T}$-cells) immune responses. IL-12 is a main factor in driving development of T-cell helper type 1 $\left(\mathrm{T}_{\mathrm{H}} 1\right)$ immunity $[112,113]$. These regulatory effects of lactoferrin on proinflammatory cytokines and IL-12 clearly illustrate its function as a bridge between the innate and adaptive immune responses.

\section{Mediation of Antigen Presentation Cell Function by Lactoferrin}

The modulation of APCs by lactoferrin has the potential to affect T-cell activity associated with specific antigenic recognition [114]. Professional antigen presenting cells, macrophages, dendritic cells and B cells present antigens to $\mathrm{CD}^{+}{ }^{+} \mathrm{T}$-cells via major histocompatibility complex II (MHC II), referred to as human leukocyte antigen (HLA) DR, $\mathrm{DP}$, and DQ in humans. While macrophages and dendritic cells play a distinct role in maintaining, augmenting, and generating antigen specific T-cell functions and activities, the primary function of B-cells is to utilize specific surface receptors (antibodies) to capture foreign antigens and present associate epitopes to $\mathrm{T}$ cells to allow further maturation of the antibody response and isotype switching. The effects of lactoferrin on APCs are as varied as those observed for T-cell populations (described below), with results often dependent upon experimental parameters.

Macrophages-Macrophages are professional APC that function in the innate immune response through phagocytosis of foreign bodies followed by subsequent release of proinflammatory mediators. They also interact with the adaptive immune system to stimulate antigen-specific T-cells. Receptors for lactoferrin, both bovine and human forms, are present on macrophages, as assessed by binding studies [115]. Numerous studies have focused on lactoferrin's suppressive effects towards proinflammatory cytokines and type I interferon (IFN- $\alpha / \beta)$ production, and it's promotion in generating reactive oxygen species (such as inducible nitric oxide) [96,116]. For example, lactoferrin can decrease TNF- $\alpha$, IL-6, IL-1 $\beta$ produced from BCG (bacille Calmette-Guerin strain of Mycobacterium bovis) infected bone marrow derived macrophages (Fig. 7). Lactoferrin can also increase 
phagocytic activity from unstimulated, LPS stimulated, or infected (vesicular stomatitis virus, Candida albicans, or BCG) macrophages [111,117].

In addition to the modulation of these innate activities of macrophages, lactoferrin also affects the contribution of macrophages to function as presenters of antigen to activate antigen specific $\mathrm{CD} 4^{+} \mathrm{T}$-cells of the adaptive immune system. This process induces a series of events that are essential to host control of intracellular pathogens, including macrophage migration to sites of inflammation and/or infection. Lactoferrin injected into mice sensitized to SRBC suppressed the inhibition of macrophage migration by migration inhibition factor [118]. At the site of inflammation/infection, stimulation of antigen specific $\mathrm{CD} 4^{+} \mathrm{T}$-cells requires presentation of antigenic peptides by macrophages via MHC II and co-stimulatory signals CD80, CD86, and CD40. BCG infected bone marrow derived macrophages that were stimulated with IFN- $\gamma$, demonstrated suppressed expression of MHC II which was partially rescued by bovine lactoferrin [119]. Lactoferrin increased surface expression of CD40 on murine macrophage cell line (RAW 264.7) and peritoneal macrophages, with levels comparable to LPS treatment [120]. The expression of CD80 and CD86 is also modulated differentially by lactoferrin. CD80 expression is significantly suppressed in bone marrow derived macrophages treated with BCG in the presence of lactoferrin, with no changes in CD86 even upon activation with IFN- $\gamma$ [119]. The increase in the ratio of CD86: CD80 suggests that lactoferrin treated BCG infected bone marrow derived macrophages are more capable of stimulating T-cell activation during antigen presentation [121,122]. Indeed, bone marrow derived macrophages cultured with BCG in the presence of lactoferrin stimulated higher production of IFN $-\gamma$ from BCG sensitized $\mathrm{CD}^{+}$and $\mathrm{CD} 4^{+}$splenocytes compared to similarly treated cells without lactoferrin [119].

One of the major cytokines produced by macrophages is IL-12, an important modulator of the $\mathrm{T}_{\mathrm{H}} 1$ cytokine, IFN- $\gamma$. Macrophages, especially at the site of infection, are a main source of IL-12 [123,124], which acts as a co-stimulator to maximize secretion of IFN- $\gamma$ from differentiated $\mathrm{T}_{\mathrm{H}} 1$ cells and memory T-cells $[125,126]$. Peritoneal macrophages isolated from mice after intraperitoneal injection of lactoferrin demonstrated increased production of IL-12 [50]. LPS stimulated macrophages (bone marrow derived, as well as J774A.1 and Raw 264.7 cell lines) infected with BCG increased ratio of IL-12 compared to IL-10, a main negative regulator of IL-12 [50,110,111]. Similar results were found in vivo; the expression of message in the small intestines of mice fed lactoferrin exhibited a similar increase in IL-12p40 with a concurrent decrease of IL-10 [108]. In addition, it is of interest to note that culturing of peritoneal macrophages with lactoferrin elevated levels of IL-18, a cytokine that has shown to act in concert with IL-12 to increase IFN- $\gamma$ production, and caspase-1, an enzyme that modifies IL-18 into the active form [127-129].

Dendritic Cells-The dendritic cell APCs are comprised of a group of functionally related professional phagocytes that can manipulate naïve T-cell differentiation [130] and redirect memory T-cell functions $[131,132]$. The ability of lactoferrin to promote antigen specific DTH responses and BCG specific T-cell activation indicates a role in the initiation of T-cell activation, perhaps through modulation of dendritic cell function. Similar to macrophages, dendritic cells possess lactoferrin receptors as both bovine and human lactoferrin can bind to the surface of peripheral blood derived dendritic cells $[102,133]$.

Majority of studies on lactoferrin effecting dendritic cell functions focus on Langerhan cells (LC), epidermal dendritic cells that induce and regulate skin/epidermal immune responses, such as demonstrated in LCs migration in allergen-induced models. Mice given recombinant lactoferrin intradermally in the ear pinnae 2 hours prior to injection of the chemical allergen inhibited LCs from migrating into the lymph node [134]. Prior application (2 or $4 \mathrm{~h}$ ) of recombinant human lactoferrin on volunteers exposed topically to the contact allergen DPC 
(diphenylcyclopropenone) also prevented LC migration from the skin [135-137]. Both mouse and human recombinant lactoferrin decrease LC migration induced by IL-1 $\beta$, but not TNF- $\alpha$; administration of lactoferrin suppressed the production of de novo TNF- $\alpha$ stimulated by application of IL-1 $\beta[134,135]$. This effect of lactoferrin to decrease stimulation induced production of cytokines is well documented, as mentioned previously. Even dendritic cells derived from murine bone marrow, when stimulated with LPS, decreased production of IL-12 and IL-1 $\beta$ when cultured with lactoferrin [138].

The ability of dendritic cells to migrate upon stimulation or capture of antigen is important in its function to promote development of antigen specific immune responses, as is its ability to mature, defined by a decrease in antigen uptake and increased expression of MHC II, CD86, CD40 and stimulation of T-cells. It was noted that recombinant lactoferrin can marginally increase expression of CD86 in dendritic cells stimulated with nickel sulphate [139]. Recently, evidence suggests that recombinant lactoferrin may act as a maturation factor for human monocyte derived dendritic cells. Immature dendritic cells cultured with lactoferrin upregulate surface expression of a series of maturation markers, including HLA II (human leukocyte antigen II), CD80, CD86, and CD83, all of which are involved in antigen presentation and activation of $\mathrm{CD}^{+} \mathrm{T}$-cells. Chemokine receptors associated with migration and homing to draining lymph nodes were similarly elevated from immature DCs cultured with lactoferrin. More importantly, lactoferrin matured dendritic cells increased production of $\mathrm{T}_{\mathrm{H}} 1$ modulating cytokine, IL-12, with concurrent decrease of the negative regulator IL-10 and a $\mathrm{T}_{\mathrm{H}} 2$ modulating cytokine IL-6. Lastly, lactoferrin cultured immature DCs exhibit other maturation functions, exhibited by decreased antigen uptake and increased T-cell stimulation [140].

Our studies on the effect of lactoferrin on murine bone marrow derived dendritic cells (BMDCs) are in good agreement with the above mentioned findings. While lactoferrin does not promote maturation of immature murine BMDCs during BCG infection, the addition of lactoferrin does maintain expression of the dendritic cell marker, CD11c (personal communication; S-A. Hwang). Visually, addition of lactoferrin to uninfected or BCG infected BMDCs appears to promote dendritic cell morphological changes, as evident by elongated cellular bodies with extending pseudopodia. Whereas, BMDCs cultured without lactoferrin possess a more rounded cellular appearance (data not shown). In addition, murine BMDCs treated with BCG and lactoferrin increased expression of the migration marker CD62L, a marker that traffics cells to the draining lymph node. Concurrently, CD44 expression in non-infected BMDCs decreased, lowering non-specific migration events at sites of inflammation (Fig. 8). This is a novel finding, with the suggestion that lactoferrin may have differential effects on BMDCs compared to epidermal DCs (LC), relative to migration events. Taken together, these studies point to the possibility that lactoferrin overcomes the natural downregulation of BCG on dendritic cell function. Overall, lactoferrin is a strong mediator of dendritic cell function. These observations, combined with the effects detailed above on macrophages, suggest that lactoferrin exerts its effect on cells involved in primary engagement of pathogens (antigens) that have potential to direct development of subsequent adaptive immunity.

\section{Lactoferrin Modulates Antigen Specific Adaptive Immune Responses}

The above effects of lactoferrin on APC activation, maturation, migration, and antigen presentation suggest that lactoferrin has a unique ability to bridge innate and adaptive cell function, for both $\mathrm{T}$ cells as well as B cell responses.

T lymphocytes-The link between cellular and humoral responses is strong, and many cytokines and mediators have been identified as early mediators of effector $\mathrm{T}$ cell 
development [141]. The adaptive immune response is dominated by T-cell $\left(\mathrm{CD}^{+}\right)$activity, which encompasses differentially functional subsets. In the context of lactoferrin, most studies have focused mainly on $\mathrm{CD} 4^{+} \mathrm{T}$-cells and its two well-studied differentiation generated subsets, $T$-cell helper type $1\left(\mathrm{~T}_{\mathrm{H}} 1\right)$ and type $2\left(\mathrm{~T}_{\mathrm{H}} 1\right) . \mathrm{T}_{\mathrm{H}} 1$ cells "help" stimulate and activate macrophages, resulting in intracellular killing events to eliminate intracellular pathogens often through production of reactive oxygen mediates. The $\mathrm{T}_{\mathrm{H}} 2$ subtype stimulates and activates B-cells, enabling isotype switching and promoting production of antigen specific antibodies [142,143]. A third subset, the more recently defined $\mathrm{T}_{\mathrm{H}} 17$ subset through to be associated with clinical disease progression, has not yet been examined for affect by lactoferrin [141].

Expression of lactoferrin receptors have been reported on all T-cell subsets, including $\delta \gamma \mathrm{T}$ cells [98]. Both bovine and human lactoferrin are capable of binding to surface receptors on the human T-cell line (Jurkat) $[144,145]$, the binding of which may be involved in receptormediated endocytosis [146]. T-cells are affected by lactoferrin in a variety of ways, often depending on their current state of maturation, differentiation, and/or activation. Human milk-derived lactoferrin is able to mature $\mathrm{CD} 4^{-} \mathrm{CD} 8^{-}$murine T-cells, with a preference towards expression of CD4 [49], primarily through induced intracellular MAP kinase pathways via Erk2 and a requirement for p56 ${ }^{\mathrm{lck}}$ (kinase specific to lymphocytes) [147]. Expression of human T-cell $\zeta$-chain, part of the T-cell receptor (TCR) complex and involved in receptor signaling, is increased by human lactoferrin [148]. An adhesion molecule, leukocyte function associated antigen (LFA-1), present on both $\mathrm{CD}^{+}$and $\mathrm{CD} 8^{+} \mathrm{T}$-cells and involved in cell-to-cell contact is similarly upregulated in human peripheral blood mononuclear cells cultured with human lactoferrin [46]. These associated changes in surface molecules that regulate $\mathrm{T}$-cell function suggest that lactoferrin is capable of modulating $\mathrm{T}$ cell activity and reactivity to local antigens.

As previously discussed, lactoferrin exerts anti-inflammatory and stimulatory effects; affects on T-cells also exhibit this duality in response [149]. Addition of lactoferrin to mitogen activated T-cells decreases overall cytokine production [150]. ConA stimulated murine splenocytes (non-adherent) cultured with bovine or human milk lactoferrin demonstrate decreased production of IFN- $\gamma$ and IL-2 (Fig. 9). In a nickel induced T-cell activation model, a recombinant lactoferrin decreased T-cell proliferation, cytokine production (IL-5), and chemokine receptor expression (CCR4) [151]. Conversely, in vivo examination of delayed type hypersensitivity (DTH), a T-cell mediated response, found that introduction of lactoferrin enhanced the DTH response as measured by footpad swelling to a variety of antigens, including ovalbumin, sheep red blood cells, and BCG [50,152,153]. Indeed, administered lactoferrin can potentiate the restoration of humoral immune response in immunocompromised hosts [154,155], suggesting a mechanism for stimulating adaptive cell reconstitution through proliferative pathways. In a murine model of immune suppression induced by an immune suppressive agent (cyclophosphamide) or stress, lactoferrin delivered either orally or intraperitoneally restored the host DTH response, in part by increasing circulating T-cell populations [154,156,157]. Mice orally fed lactoferrin increased circulating total leukocytes, $\mathrm{CD}^{+} \mathrm{CD}^{+}, \mathrm{CD}^{+} \mathrm{TCR} \gamma \delta^{+}$, and granulocyte populations [108]. In mice implanted with tumor cells, oral delivery of lactoferrin elevated the lymphoid and intestinal resident $\mathrm{CD} 4^{+}$and $\mathrm{CD} 8^{+} \mathrm{T}$-cells [158].

The effect of lactoferrin on T-cell populations can be further delineated into specific targeting of cellular subset responses. A well studied phenomenon is the ability of lactoferrin to modulate and direct changes in the balance of $\mathrm{T}_{\mathrm{H}} 1$ and $\mathrm{T}_{\mathrm{H}} 2$ immunity often defined by the T-cell cytokines IFN- $\gamma$ and IL- 4 and IL- 5 respectively. As with the overall Tcell response, lactoferrin is capable of affecting both $\mathrm{T}_{\mathrm{H}} 1$ and $\mathrm{T}_{\mathrm{H}} 2$ cellular subsets. The effects appear to be dependent on activation events, relative to complexity of stimulus or 
antigen. A comparison in delivery of lactoferrin reported that mitogen stimulated (ConA) splenocytes from mice orally given lactoferrin increased $\mathrm{T}_{\mathrm{H}} 2$ cytokines whereas injection with lactoferrin intramuscularly increased IL-2 (a $\mathrm{T}_{\mathrm{H}} 1$ associated T-cell cytokine) [159]. Lactoferrin suppressed IFN- $\gamma$ production from anti-CD3/CD28 activated human CD4 ${ }^{+}$Tcells [160]. In a Toxoplasma gondii infection model, oral lactoferrin favored a $\mathrm{T}_{\mathrm{H}} 2$ response in the gut mucosa, observed by a decrease in IFN- $\gamma$ and elevation in IL-10 $\left(a \mathrm{~T}_{\mathrm{H}} 2\right.$ associated cytokine) [161]. Lactoferrin inhibited proliferation of a $\mathrm{T}_{\mathrm{H}} 1$ cell line but not a $\mathrm{T}_{\mathrm{H}} 2$ cell line. This inhibition correlated to changes in receptors for autocrine growth factors, IL-2 and IL-4 [162]. Lactoferrin reduced surface expression of IL-2R on $T_{H} 1$ cells, whereas there were no changes in expression of IL-4R on $\mathrm{T}_{\mathrm{H}} 2$ cells during antigen stimulation [163].

In contrast, orally administered lactoferrin given to multiple sclerosis patients, naive mice, or tumor-carrying mice increased IFN- $\gamma$ levels $[157,158,164]$, indicating an increase in $\mathrm{T}_{\mathrm{H}} 1$ T-cell response. Similarly, Staphylococcus aureus infection of transgenic mice expressing human lactoferrin saw a shift of host responses towards $\mathrm{T}_{\mathrm{H}} 1$, as observed by increased levels of IFN- $\gamma$ and TNF- $\alpha$ and decreased IL-5 and IL-10 [165]. This polarization of host immunity towards $\mathrm{T}_{\mathrm{H}} 1$ by lactoferrin can remain even after the initial T-cell activation subsided. In one specific example of polarization, recall responses in mice vaccinated with BCG/lactoferrin exhibited higher production of IFN- $\gamma$ compared to mice immunized with BCG only [166,167]. The ability of lactoferrin to modulate antigen-specific T-cell response that can last several weeks after the initial sensitization suggest that lactoferrin affects events during priming of naïve T-cells to specific antigens.

B lymphocytes-In addition to lactoferrin's role as a modulator of excessive response, an eloquent series of experiments demonstrated that lactoferrin can also function to enhance depleted immunoreactivity. This is most evident in the role of lactoferrin to affect B lymphocytes. Lactoferrin has the ability to promote maturation of murine immature B-cells, evident by increasing complement 3 receptor $(\mathrm{C} 3 \mathrm{R})$ expression and promoting acquisition of surface IgD. Immature B-cells cultured with lactoferrin increased their ability to promote antigen-specific T-cell proliferation, indirectly indicating enhanced B-cell antigen presentation [48]. B-cell presented antigens specifically stimulated T-cells to induce cytokines required for isotype switching events. Oral delivery of lactoferrin increased secretion of overall IgA and IgG from murine Peyer's patches [168] with specific antibody titers remaining elevated in both serum and intestinal secretions [159]. In a chemotherapyinduced immune suppression murine model, lactoferrin given intraperitoneally prior to a sub-lethal dose of cyclophosphamide lessened the suppression of antibody forming cells. Lactoferrin was also able to facilitate restoration of the immune response [156]. In another series of experiments, lactoferrin specifically exhibited the ability to overcome the suppressive action of methotrexate in the secondary, humoral immune response to sheep erythrocytes in mice [169]. Furthermore, the biological activity of different glycoforms was tested in vitro, revealing the importance of $\mathrm{N}$-acetylneuraminic (sialic) acid as a terminal sugar in propagation of the reconstituted immune responses [170]. Consequentially, this suggests that lactoferrin can act on B cells, a known antigen presenter, to allow subsequent $\mathrm{T}$ cells interactions that favor elevation of the antibody response.

\section{ADJUVANT ACTIVITY OF LACTOFERRIN}

Because of the above stated effects of lactoferrin on cells involved in antigen presentation, as well as on its direct mediation of lymphocyte function, it is an excellent candidate for use as an adjuvant. Lactoferrin has clearly demonstrated ability to promote T-cell mediated delayed-type hypersensitivity against a variety of antigens, including experimental antigens ovalbumin and sheep red blood cells, as well as antigens of critical therapeutic importance, 
such as BCG [50,153]. Indeed, the potential for use of lactoferrin adjuvant even extends to other species, including fish [171,172].

A promising utility for lactoferrin as an adjuvant is for enhancing the efficacy of the tuberculosis vaccine. Our laboratory demonstrated that lactoferrin add-mixed into the immunization formulation with BCG is able to augment efficacy of the BCG vaccine to confer additional protection in the lung and spleen against aerosol MTB challenge, with generation of increased cytokines critical for protective DTH response of a TH1 profile $[50,110,111,166,167]$. One remarkable finding was that addition of lactoferrin to the BCG vaccine led to reduced pathological damage upon subsequent infection with virulent MTB. Positive results were demonstrated when admixed in oil-based vehicle (incomplete Freund's adjuvant) or when given with BCG in saline in a single dose or with a booster at 2 weeks $[50,167]$ with decreased organ bacterial load compared to non-immunized controls $[166,167]$ and reduced lung histopathology (Fig. 10). The tuberculosis induced granulomatous response from mice immunized with BCG/lactoferrin had an apparent reduction in lung inflammatory responses, showing normal lung parenchyma surrounding granulomas that were visually highly lymphocytic in composition. Similar findings hold true using a novel recombinant human lactoferrin (personal communication, J. Actor).

While lactoferrin itself is an effective adjuvant for development of DTH, others have tried to improve efficacy using a linked monophosphoryl lipid A complex to stimulate humoral and cellular immune response to ovalbumin and sheep red blood cells [173]. The same group also demonstrated enhanced immunity against Plesiomonas shigelloides using the lactoferrin-monophosphoryl lipid A complex [174]. Finally, numerous trials have examined lactoferrin to modulate responses to cancer antigens, for use in prophylactic or therapeutic treatment [175-179].

\section{RECEPTORS FOR LACTOFERRIN ON IMMUNE SYSTEM CELLS}

The effort to identify lactoferrin receptor(s) that are responsible for the immune modulatory activities observed proves to be challenging. Recent and significant discoveries have expanded the identification of receptor(s) responsible for lactoferrin effects on leukocytes. Lactoferrin was first identified as an important defense component of colostrum and mature milk, thereby promoting the hypothesis that its function involves protecting neonatal gut barriers. In concurrence with this hypothesis, lactoferrin receptor (LfR) was first discovered in the small intestinal through examination of iron delivery to the duodenal mucosa [180]. A recent study of LfR in mouse small intestine suggests that lactoferrin may act as the main source of iron during early stages of life [181]. Subsequent binding affinity studies identified LfR on B-cell, T-cells, and monocytes [97,182-184], as well as on platelets [185], and intestinal cells [180]. The low-density lipoprotein receptor-related protein-1 and -2 (LRP1 and LRP2), which are multi-ligand receptors, are considered primary lactoferrin receptors. Although members of the LRP family are generally considered endocytic receptors, it has been suggested that LRP1 also functions as a signaling receptor [186].

The receptors for lactoferrin can be subdivided according to potential immune function. The LfR is described as a $\sim 105 \mathrm{kDa}$ surface protein expressed on activated human lymphocytes [187]. Human Jurkat T-cells internalize and release human lactoferrin, with $30-40 \%$ of lactoferrin degraded each cycle [146]. The specificity of LfR can cross species barriers. Human monocytes bind human lactoferrin [188], with similar interactions observed in Bcells [97,189]. Likewise, murine peritoneal macrophages uptake human lactoferrin [190]. Additionally, other cell types possess LfR and are capable of internalizing lactoferrin, including murine and bovine brain endothelial capillary cells [191,192], rat hepatocytes 
[193], and human placental cytotrophoblast cell line [194]. The mechanism of LfR endocytosis appears to be clathrin mediated [97,194].

Studies on lactoferrin binding affinities to target cells identify low affinity binding sites, believed to be mediated by sulfated chains of proteoglycans [183]. Both bovine and human lactoferrin bind to the surface of THP-1 cells, a human monocytic cell line. Binding can be reduced by inhibiting sulphation on the cell surface $[115,133,195]$. Both human and bovine lactoferrin bind purified heparin sulfate chains, and to a lesser extent, chondroitin sulfate chains. The decrease in ability of lactoferrin to prevent viral infectivity of heparin deficient or heparin and chondroitin deficient murine L fibroblasts demonstrates the specificity of lactoferrin to glycosaminoglycans [196].

The anti-inflammatory effects of lactoferrin on leukocytes stimulated with LPS are well known. These anti-inflammatory effects of lactoferrin directly relates to interaction with proteins involved in LPS signaling. Lipopolysaccharide-binding protein (LBP) is a secreted protein that facilitates LPS binding to CD14, a co-receptor for toll-like receptor 4 (TLR-4), to enhance LPS stimulation of the target cell. Milk-derived lactoferrin competes with LPS for LPB and subsequently, can decrease LPS binding to CD14 [23,197]. Similarly, human lactoferrin is capable of interacting with soluble CD14 to prevent CD14-LPS induction of adhesion molecule expression [198]. However, there are no reports of direct interaction of lactoferrin with the signaling molecule, TLR-4. Indirectly, TLR-4 plays no role in bovine lactoferrin induced IL- 6 production from murine peritoneal cells, but TLR-4 expression is required for optimal lactoferrin stimulated expression of CD40 [120]. Another study showed that TLR-4 is required for lactoferrin to activate the anti-viral state in host cells against vesicular stomatitis virus, but TLR-4 is dispensable in lactoferrin stimulation of TNF- $\alpha$ production [96]. Recently, the anti-inflammatory effect of lactoferrin on B-cells is attributed to its ability to bind CpG-containing oligonucleotides $[199,200]$, promoting the possibility that lactoferrin may interact with TLR-9.

\section{IMPORTANCE OF SUGAR RESIDUES ON LACTOFERRIN FOR IMMUNE ACTIVATION}

The key to understanding the molecular basis of lactoferrin various activities is thought to reside in part according to patterns of glycosylation [201]. There are three possible N-linked glycosylation sites in human lactoferrin, one at Asn138, a second site at Asn479, and a third site at Asn624; differential utilization of these sites results in distinct glycosylation variants. Human lactoferrin glycans are the $\mathrm{N}$-acetyllactosaminic type, $\alpha 1,3$-fucosylated on the $\mathrm{N}$ acetyl-glucosamine residue linked to the peptide chain. Unlike the milk-derived lactoferrin, the neutrophilic form however is not fucosylated, and the difference in molecular structure and function of the two forms is not fully understood. Furthermore there is antigenic variation between human and bovine lactoferrins, mostly due to approximately 70-77\% amino acid sequence homology but also due to distinct glycosylation patterns. There are at least 5 glycosylation sites present on bovine lactoferrin; Asn-233, Asn-2281, Asn-368, Asn-476 and Asn-545. In addition the glycans present on at least two of these sites (Asn-233 and Asn-545) are of the high mannose type [202]. The others are complex-type glycans that likely contain mannose moieties (Table 2).

A recent study highlighted the importance of these glycans, in particular the residual sugars, regarding the biological activity of the recombinant human lactoferrin glycoforms glycoengineered in Pichia pastoris. The importance of $\mathrm{N}$-acetylneuraminic (sialic) acid as a terminal sugar in propagation of lactoferrin mediated immune response was demonstrated in a study designed to overcome the suppressive action of methotrexate in the secondary, humoral immune response in mice [170]. Another indirect method linking lactoferrin to 
mechanisms that overcome suppression may include IL-8, a chemokine that binds proteoglycans. Lactoferrin may participate in the formation of chemokine gradients at sites of inflammation. Specifically, human lactoferrin effectively competes with IL-8 for proteoglycan binding sites, and may serve as an explanation of the anti-inflammatory effects of lactoferrin observed in in vivo sepsis models [203].

As lactoferrin contains multiple sites for glycosylation, it is recognized by the group of Ctype lectin receptors, which includes mannose receptor and DC-SIGN (specific ICAM-3grabbing non-integrin). Indeed, dendritic cells pre-treated with bovine lactoferrin inhibit infection with HIV-1, resulting from lactoferrin binding to DC-SIGN to block its interaction with gp-120 (HIV envelope protein) and prevent virus transmission [102]. Glycosylation is also required for lactoferrin's adjuvant activities; increased generation of delayed type hypersensitive response to ovalbumin can be abolished by addition of methyl- $\alpha$-Dmannopyranoside [47,152]. Briefly, the adjuvant activity of lactoferrin in the generation of DTH to antigen can be inhibited by bovine serum albumin bearing alpha-D-mannopyranosyl residues. Inhibition of the effector DTH response could be specifically reversed by methylalpha-D-mannopyranoside (MMan) but not by D-galactose (Gal). Comparative studies between bovine and human lactoferrins (BLF and HLF) revealed that the adjuvant effect of BLF was stronger than that of HLF; nevertheless, both effects were inhibited by MMan. Thus, it is postulated that the mannose receptor (MR) is a primary receptor for lactoferrin in mediation of its immunotropic activities. However, there are no studies that report evidence of direct binding of lactoferrin to the mannose receptor.

Identifying sugar residues on lactoferrin that mediate interactions with receptors that bind and/or participate in the various immune regulatory functions of lactoferrin remains an ongoing research goal. While many receptors have been identified, most of the known receptors function in the endocytic process or as adhesion molecules but have limited intracellular signaling activities. The challenge in understanding the mechanism of lactoferrin in modulating functions of leukocytes is in sorting through the various potential binding possibilities to identify specific signaling receptors.

\section{CONCLUSIONS}

Lactoferrin is a key element to combat excessive inflammation and direct host immune function to protect against overaggressive microbial insults. Found in exocrine secretions, lactoferrin serves as a natural regulator of host defense. It is one of the first factors released by neutrophils upon encounter with pathogens and contributes to innate activation by directing development of adaptive responses. In combination with its historical role in limiting microbial proliferation and functioning as a direct microbicidal agent, lactoferrin plays a central role in host immunity. Lactoferrin has the ability to modulate cytokine production from monocytes, as well as from lymphocytes, during activation from foreign stimuli or mitogens. In addition, along with co-stimulatory mediators, lactoferrin can modulate chemokine recognition and lymphocyte migratory potential. This, coupled with the ability to affect production and activity of reactive oxygen species, allows lactoferrin to serve as a unique regulator to a wide array of responses, including those involved in septic shock (e.g. systemic inflammatory response syndrome), inflammation, and subsequent development of disease related pathologies.

\section{Acknowledgments}

Research was supported by the National Institute of Allergy and Infectious Diseases (R42AI051050-02) and the National Institute of General Medical Sciences (1R41GM-079810-01), granted in part to the University of TexasHouston Health Science Center and PharmaReview Corporation, Houston, TX. 


\section{ABREVIATIONS}

$\begin{array}{ll}\text { APC } & \text { Antigen presenting cell } \\ \text { BCG } & \text { Bacille Calmette-Guérin } \\ \text { BMDCs } & \text { Bone marrow derived dendritic cells } \\ \text { CFU } & \text { Colony forming unit } \\ \text { Con A } & \text { Concanavalin A } \\ \text { DTH } & \text { Delayed type hypersensitivity } \\ \text { E. coli } & \text { Escherichia coli } \\ \text { ELISA } & \text { Enzyme-linked immunosorbent assay } \\ \text { FITC } & \text { Fluorescein isothiocyanate } \\ \text { GO } & \text { Glucose oxidase } \\ \text { H\&E } & \text { Hematoxylin and eosin } \\ \text { HLA } & \text { Human leukocyte antigen } \\ \text { HSA } & \text { Human serum albumin } \\ \text { IFN- } \gamma & \text { Interferon-gamma } \\ \text { IL-\# } & \text { Interleukin-\# } \\ \text { LF } & \text { Lactoferrin } \\ \text { LPS } & \text { Lipopolysaccharide } \\ \text { MHC } & \text { Major histocompatability complex } \\ \text { MRSA } & \text { Methicillin-resistant Staphylococcus aureus } \\ \text { MTB } & \text { Mycobacterium tuberculosis } \\ \text { NK } & \text { Natural killer cell } \\ \text { ROS } & \text { Reactive oxygen species } \\ \text { SIRS } & \text { Systemic inflammatory response syndrome } \\ \text { SOD } & \text { Superoxide dismutase } \\ \text { SRBC } & \text { Theep red blood cells } \\ \text { Th1/Th2 } & \text { T helper cell type 1/T helper cell type 2 } \\ \text { TNF- } \alpha & \text { Tumor necrosis factor alpha } \\ \text { z-DEVD-fmk } & \text { N-Benzyloxycarbonyl-Asp(OMe)-Glu(OMe)-Val-Asp(OMe)-fluoro- } \\ & \end{array}$

\section{References}

1. Chodaczek G, Saavedra-Molina A, Bacsi A, Kruzel ML, Sur S, Boldogh I. Iron-mediated dismutation of superoxide anion augments antigen-induced allergic inflammation: effect of lactoferrin. Postepy Hig Med Dosw (Online) 2007;61:268-76. [PubMed: 17507875]

2. Kruzel ML, Actor JK, Boldogh I, Zimecki M. Lactoferrin in health and disease. Postepy Hig Med Dosw (Online) 2007;61:261-7. [PubMed: 17507874]

3. Legrand D, Pierce A, Elass E, Carpentier M, Mariller C, Mazurier J. Lactoferrin structure and functions. Adv Exp Med Biol 2008;606:163-94. [PubMed: 18183929] 
4. Baker EN, Baker HM. Molecular structure, binding properties and dynamics of lactoferrin. Cell Mol Life Sci 2005;62:2531-9. [PubMed: 16261257]

5. Baggiolini M, De Duve C, Masson PL, Heremans JF. Association of lactoferrin with specific granules in rabbit heterophil leukocytes. J Exp Med 1970;131:559-70. [PubMed: 5413328]

6. Lonnerdal B, Iyer S. Lactoferrin: molecular structure and biological function. Annu Rev Nutr 1995;15:93-110. [PubMed: 8527233]

7. Sanchez L, Calvo M, Brock JH. Biological role of lactoferrin. Arch Dis Child 1992;67:657-61. [PubMed: 1599309]

8. Clare DA, Catignani GL, Swaisgood HE. Biodefense properties of milk: the role of antimicrobial proteins and peptides. Curr Pharm Des 2003;9:1239-55. [PubMed: 12769734]

9. Baveye S, Elass E, Mazurier J, Spik G, Legrand D. Lactoferrin: a multifunctional glycoprotein involved in the modulation of the inflammatory process. Clin Chem Lab Med 1999;37:281-6. [PubMed: 10353473]

10. Baynes RD, Bezwoda WR. Lactoferrin and the inflammatory response. Adv Exp Med Biol 1994;357:133-41. [PubMed: 7762425]

11. Kruzel ML, Harari Y, Mailman D, Actor JK, Zimecki M. Differential effects of prophylactic, concurrent and therapeutic lactoferrin treatment on LPS-induced inflammatory responses in mice. Clin Exp Immunol 2002;130:25-31. [PubMed: 12296849]

12. Bellamy W, Takase M, Yamauchi K, Wakabayashi H, Kawase K, Tomita M. Identification of the bactericidal domain of lactoferrin. Biochim Biophys Acta 1992;1121:130-6. [PubMed: 1599934]

13. Tomita M, Bellamy W, Takase M, Yamauchi K, Wakabayashi H, Kawase K. Potent antibacterial peptides generated by pepsin digestion of bovine lactoferrin. J Dairy Sci 1991;74:4137-42. [PubMed: 1787185]

14. Zagulski T, Lipinski P, Zagulska A, Broniek S, Jarzabek Z. Lactoferrin can protect mice against a lethal dose of Escherichia coli in experimental infection in vivo. Br J Exp Pathol 1989;70:697-704. [PubMed: 2690922]

15. Jenssen H, Hancock RE. Antimicrobial properties of lactoferrin. Biochimie. 2008

16. Farnaud S, Evans RW. Lactoferrin--a multifunctional protein with antimicrobial properties. Mol Immunol 2003;40:395-405. [PubMed: 14568385]

17. Vorland LH. Lactoferrin: a multifunctional glycoprotein. Apmis 1999;107:971-81. [PubMed: 10598868]

18. Ellison RT 3rd, Giehl TJ. Killing of gram-negative bacteria by lactoferrin and lysozyme. J Clin Invest 1991;88:1080-91. [PubMed: 1918365]

19. Ward PP, Paz E, Conneely OM. Multifunctional roles of lactoferrin: a critical overview. Cell Mol Life Sci 2005;62:2540-8. [PubMed: 16261256]

20. Orsi N. The antimicrobial activity of lactoferrin: current status and perspectives. Biometals 2004;17:189-96. [PubMed: 15222464]

21. Valenti P, Antonini G. Lactoferrin: an important host defence against microbial and viral attack. Cell Mol Life Sci 2005;62:2576-87. [PubMed: 16261253]

22. Weinberg ED. Antibiotic properties and applications of lactoferrin. Curr Pharm Des 2007;13:80111. [PubMed: 17430182]

23. Amati L, Caradonna L, Leandro G, Magrone T, Minenna M, Faleo G, et al. Immune abnormalities and endotoxemia in patients with ulcerative colitis and in their first degree relatives: attempts at neutralizing endotoxin-mediated effects. Curr Pharm Des 2003;9:1937-45. [PubMed: 12871178]

24. Adamik B, Zimecki M, Wlaszczyk A, Kubler A. Immunological status of septic and trauma patients. I. High tumor necrosis factor alpha serum levels in septic and trauma patients are not responsible for increased mortality; a prognostic value of serum interleukin 6. Arch Immunol Ther Exp (Warsz) 1997;45:169-75. [PubMed: 9597083]

25. Adamik B, Zimecki M, Wlaszczyk A, Kubler A. Immunological status of septic and trauma patients. II. Proliferative response and production of interleukin 6 and tumor necrosis factor alpha by peripheral blood mononuclear cells from septic survivor, nonsurvivor and trauma patients: a correlation with the survival rate. Arch Immunol Ther Exp (Warsz) 1997;45:277-84. [PubMed: 9523001] 
26. Puddu P, Borghi P, Gessani S, Valenti P, Belardelli F, Seganti L. Antiviral effect of bovine lactoferrin saturated with metal ions on early steps of human immunodeficiency virus type 1 infection. Int J Biochem Cell Biol 1998;30:1055-62. [PubMed: 9785469]

27. van der Strate BW, Beljaars L, Molema G, Harmsen MC, Meijer DK. Antiviral activities of lactoferrin. Antiviral Res 2001;52:225-39. [PubMed: 11675140]

28. Giansanti F, Rossi P, Massucci MT, Botti D, Antonini G, Valenti P, Seganti L. Antiviral activity of ovotransferrin discloses an evolutionary strategy for the defensive activities of lactoferrin. Biochem Cell Biol 2002;80:125-30. [PubMed: 11908636]

29. Jenssen H. Anti herpes simplex virus activity of lactoferrin/lactoferricin -- an example of antiviral activity of antimicrobial protein/peptide. Cell Mol Life Sci 2005;62:3002-13. [PubMed: 16261265]

30. Seganti L, Di Biase AM, Marchetti M, Pietrantoni A, Tinari A, Superti F. Antiviral activity of lactoferrin towards naked viruses. Biometals 2004;17:295-9. [PubMed: 15222481]

31. Gifford JL, Hunter HN, Vogel HJ. Lactoferricin: a lactoferrin-derived peptide with antimicrobial, antiviral, antitumor and immunological properties. Cell Mol Life Sci 2005;62:2588-98. [PubMed: 16261252]

32. Florisa R, Recio I, Berkhout B, Visser S. Antibacterial and antiviral effects of milk proteins and derivatives thereof. Curr Pharm Des 2003;9:1257-75. [PubMed: 12769735]

33. Turchany JM, Aley SB, Gillin FD. Giardicidal activity of lactoferrin and N-terminal peptides. Infect Immun 1995;63:4550-2. [PubMed: 7591103]

34. Dzitko K, Dziadek B, Dziadek J, Dlugonska H. Toxoplasma gondii: inhibition of the intracellular growth by human lactoferrin. Pol J Microbiol 2007;56:25-32. [PubMed: 17419186]

35. Tanaka T, Omata Y, Saito A, Shimazaki K, Igarashi I, Suzuki N. Growth inhibitory effects of bovine lactoferrin to Toxoplasma gondii parasites in murine somatic cells. J Vet Med Sci 1996;58:61-5. [PubMed: 8645758]

36. Cirioni O, Giacometti A, Barchiesi F, Scalise G. Inhibition of growth of Pneumocystis carinii by lactoferrins alone and in combination with pyrimethamine, clarithromycin and minocycline. $\mathrm{J}$ Antimicrob Chemother 2000;46:577-82. [PubMed: 11020255]

37. Okamoto T, Tanida T, Wei B, Ueta E, Yamamoto T, Osaki T. Regulation of fungal infection by a combination of amphotericin B and peptide 2, a lactoferrin peptide that activates neutrophils. Clin Diagn Lab Immunol 2004;11:1111-9. [PubMed: 15539515]

38. Viejo-Diaz M, Andres MT, Fierro JF. Modulation of in vitro fungicidal activity of human lactoferrin against Candida albicans by extracellular cation concentration and target cell metabolic activity. Antimicrob Agents Chemother 2004;48:1242-8. [PubMed: 15047526]

39. Ueta E, Tanida T, Osaki T. A novel bovine lactoferrin peptide, FKCRRWQWRM, suppresses Candida cell growth and activates neutrophils. J Pept Res 2001;57:240-9. [PubMed: 11298926]

40. Xu YY, Samaranayake YH, Samaranayake LP, Nikawa H. In vitro susceptibility of Candida species to lactoferrin. Med Mycol 1999;37:35-41. [PubMed: 10200932]

41. Lupetti A, van Dissel JT, Brouwer CP, Nibbering PH. Human antimicrobial peptides' antifungal activity against Aspergillus fumigatus. Eur J Clin Microbiol Infect Dis. 2008

42. Drobni P, Naslund J, Evander M. Lactoferrin inhibits human papillomavirus binding and uptake in vitro. Antiviral Res 2004;64:63-8. [PubMed: 15451180]

43. Ochoa TJ, Noguera-Obenza M, Cleary TG. Lactoferrin blocks the initial host cell attachment mechanism of Enteropathogenic E. coli (EPEC). Adv Exp Med Biol 2004;554:463-6. [PubMed: 15384625]

44. Kawasaki Y, Tazume S, Shimizu K, Matsuzawa H, Dosako S, Isoda H, et al. Inhibitory effects of bovine lactoferrin on the adherence of enterotoxigenic Escherichia coli to host cells. Biosci Biotechnol Biochem 2000;64:348-54. [PubMed: 10737192]

45. Kruzel ML, Bacsi A, Choudhury B, Sur S, Boldogh I. Lactoferrin decreases pollen antigen-induced allergic airway inflammation in a murine model of asthma. Immunology 2006;119:159-66. [PubMed: 16800860]

46. Zimecki M, Miedzybrodzki R, Mazurier J, Spik G. Regulatory effects of lactoferrin and lipopolysaccharide on LFA-1 expression on human peripheral blood mononuclear cells. Arch Immunol Ther Exp (Warsz) 1999;47:257-64. [PubMed: 10483875] 
47. Zimecki M, Kocieba M, Kruzel M. Immunoregulatory activities of lactoferrin in the delayed type hypersensitivity in mice are mediated by a receptor with affinity to mannose. Immunobiology 2002;205:120-31. [PubMed: 11999341]

48. Zimecki M, Mazurier J, Spik G, Kapp JA. Human lactoferrin induces phenotypic and functional changes in murine splenic B cells. Immunology 1995;86:122-7. [PubMed: 7590872]

49. Zimecki M, Mazurier J, Machnicki M, Wieczorek Z, Montreuil J, Spik G. Immunostimulatory activity of lactotransferrin and maturation of CD4- CD8- murine thymocytes. Immunol Lett 1991;30:119-23. [PubMed: 1683650]

50. Actor JK, Hwang SA, Olsen M, Zimecki M, Hunter RL Jr, Kruzel ML. Lactoferrin immunomodulation of DTH response in mice. Int Immunopharmacol 2002;2:475-86. [PubMed: 11962727]

51. Zimecki M, Kapp J, Machnicki M, Zagulski T, Wlaszczyk A, Kubler A, et al. Lactoferrin. Its role in maturation and function of cells of the immune system and protection against shock in mice. Adv Exp Med Biol 1998;443:331-6. [PubMed: 9781377]

52. Gutteridge JM. Hydroxyl radicals, iron, oxidative stress, and neurodegeneration. Ann N Y Acad Sci 1994;738:201-13. [PubMed: 7832429]

53. Lennon SV, Martin SJ, Cotter TG. Dose-dependent induction of apoptosis in human tumour cell lines by widely diverging stimuli. Cell Prolif 1991;24:203-14. [PubMed: 2009322]

54. Touyz RM. Oxidative stress and vascular damage in hypertension. Curr Hypertens Rep 2000;2:98105. [PubMed: 10981135]

55. Ebadi M, Srinivasan SK, Baxi MD. Oxidative stress and antioxidant therapy in Parkinson's disease. Prog Neurobiol 1996;48:1-19. [PubMed: 8830346]

56. Markesbery WR, Carney JM. Oxidative alterations in Alzheimer's disease. Brain Pathol 1999;9:133-46. [PubMed: 9989456]

57. Olanow CW, Arendash GW. Metals and free radicals in neurode-generation. Curr Opin Neurol 1994;7:548-58. [PubMed: 7866588]

58. Simonian NA, Coyle JT. Oxidative stress in neurodegenerative diseases. Annu Rev Pharmacol Toxicol 1996;36:83-106. [PubMed: 8725383]

59. Coyle JT, Puttfarcken P. Oxidative stress, glutamate, and neurode-generative disorders. Science 1993;262:689-95. [PubMed: 7901908]

60. Facchinetti F, Dawson VL, Dawson TM. Free radicals as mediators of neuronal injury. Cell Mol Neurobiol 1998;18:667-82. [PubMed: 9876873]

61. Kovacic P, Jacintho JD. Mechanisms of carcinogenesis: focus on oxidative stress and electron transfer. Curr Med Chem 2001;8:773-96. [PubMed: 11375749]

62. Parodi PW. A role for milk proteins and their peptides in cancer prevention. Curr Pharm Des 2007;13:813-28. [PubMed: 17430183]

63. Bowler RP, Crapo JD. Oxidative stress in allergic respiratory diseases. J Allergy Clin Immunol 2002;110:349-56. [PubMed: 12209079]

64. Haber F, Weiss J. On the catalysis of hydroperoxide. Naturwissenschaften 1932;20:948-50.

65. Mulder AM, Connellan PA, Oliver CJ, Morris CA, Stevenson LM. Bovine lactoferrin supplementation supports immune and antioxidant status in healthy human males. Nutr Res 2008;28:583-9. [PubMed: 19083463]

66. Gutteberg TJ, Rokke O, Andersen O, Jorgensen T. Early fall of circulating iron and rapid rise of lactoferrin in septicemia and endotoxemia: an early defence mechanism. Scand J Infect Dis 1989;21:709-15. [PubMed: 2694351]

67. Exline MC, Crouser ED. Mitochondrial mechanisms of sepsis-induced organ failure. Front Biosci 2008;13:5030-41. [PubMed: 18508567]

68. Raetz CR, Ulevitch RJ, Wright SD, Sibley CH, Ding A, Nathan CF. Gram-negative endotoxin: an extraordinary lipid with profound effects on eukaryotic signal transduction. Faseb J 1991;5:265260. [PubMed: 1916089]

69. Ulevitch RJ, Tobias PS. Receptor-dependent mechanisms of cell stimulation by bacterial endotoxin. Annu Rev Immunol 1995;13:437-57. [PubMed: 7542010] 
70. Pajkrt D, Doran JE, Koster F, Lerch PG, Arnet B, van der Poll T, et al. Antiinflammatory effects of reconstituted high-density lipoprotein during human endotoxemia. J Exp Med 1996;184:1601-8. [PubMed: 8920850]

71. Deitch EA. Multiple organ failure. Pathophysiology and potential future therapy. Ann Surg 1992;216:117-34. [PubMed: 1503516]

72. Deitch EA. Role of bacterial translocation in necrotizing enterocolitis. Acta Paediatr Suppl 1994;396:33-6. [PubMed: 8086679]

73. DeMaria, E.; Dalton, J. Bacterial translocation and the release of endotoxin and cytokines following trauma. In: Sugerman, HJ.; DeMaria, EJ., editors. Cytokines in trauma and hemorrhage. Chapman \& Hall; 1997. p. 43-61.Medical intelligence unit

74. Nadler EP, Upperman JS, Dickinson EC, Ford HR. Nitric oxide and intestinal barrier failure. Semin Pediatr Surg 1999;8:148-54. [PubMed: 10461328]

75. Kruzel ML, Harari Y, Chen CY, Castro GA. The gut. A key metabolic organ protected by lactoferrin during experimental systemic inflammation in mice. Adv Exp Med Biol 1998;443:16773. [PubMed: 9781356]

76. Zimecki M, Spiegel K, Wlaszczyk A, Kubler A, Kruzel ML. Lactoferrin increases the output of neutrophil precursors and attenuates the spontaneous production of TNF-alpha and IL-6 by peripheral blood cells. Arch Immunol Ther Exp (Warsz) 1999;47:113-8. [PubMed: 10202564]

77. Kruzel ML, Harari Y, Chen CY, Castro GA. Lactoferrin protects gut mucosal integrity during endotoxemia induced by lipopolysaccharide in mice. Inflammation 2000;24:33-44. [PubMed: 10704062]

78. Kruzel, M.; Zagulski, T.; Zimecki, M. Lactoferrin and insult-induced metabolic imbalance. Excerpta Medica International Congress Series; 4th International Congress on Lactoferrin; Sapporo, Japan. 1999.

79. Kruzel, M. Role of lactoferrin in development of Systemic Inflammatory Response Syndrome. Infection and Immunity; 2nd International Congress on Intensive Care; Wroclaw, Poland. 1998.

80. Zagulski T, Lipinski P, Zagulska A, Jarzabek Z. Antibacterial system generated by lactoferrin in mice in vivo is primarily a killing system. Int J Exp Pathol 1998;79:117-23. [PubMed: 9709381]

81. Berlyn MK. Linkage map of Escherichia coli K-12, edition 10: the traditional map. Microbiol Mol Biol Rev 1998;62:814-984. [PubMed: 9729611]

82. Tan XX, Actor JK, Chen Y. Peptide nucleic acid antisense oligomer as a therapeutic strategy against bacterial infection: proof of principle using mouse intraperitoneal infection. Antimicrob Agents Chemother 2005;49:3203-7. [PubMed: 16048926]

83. Foster TJ. Immune evasion by staphylococci. Nat Rev Microbiol 2005;3:948-58. [PubMed: 16322743]

84. Holtfreter S, Broker BM. Staphylococcal superantigens: do they play a role in sepsis? Arch Immunol Ther Exp (Warsz) 2005;53:13-27. [PubMed: 15761373]

85. McCormick JK, Yarwood JM, Schlievert PM. Toxic shock syndrome and bacterial superantigens: an update. Annu Rev Microbiol 2001;55:77-104. [PubMed: 11544350]

86. Legrand D, Elass E, Carpentier M, Mazurier J. Lactoferrin: a modulator of immune and inflammatory responses. Cell Mol Life Sci 2005;62:2549-59. [PubMed: 16261255]

87. Damiens E, Mazurier J, el Yazidi I, Masson M, Duthille I, Spik G, et al. Effects of human lactoferrin on NK cell cytotoxicity against haematopoietic and epithelial tumour cells. Biochim Biophys Acta 1998;1402:277-87. [PubMed: 9606986]

88. Shau H, Kim A, Golub SH. Modulation of natural killer and lymphokine-activated killer cell cytotoxicity by lactoferrin. J Leukoc Biol 1992;51:343-9. [PubMed: 1564398]

89. Miyauchi H, Hashimoto S, Nakajima M, Shinoda I, Fukuwatari Y, Hayasawa H. Bovine lactoferrin stimulates the phagocytic activity of human neutrophils: identification of its active domain. Cell Immunol 1998;187:34-7. [PubMed: 9682001]

90. Kawai K, Shimazaki K, Higuchi H, Nagahata H. Antibacterial activity of bovine lactoferrin hydrolysate against mastitis pathogens and its effect on superoxide production of bovine neutrophils. Zoonoses Public Health 2007;54:160-4. [PubMed: 17456148] 
91. Ward PP, Mendoza-Meneses M, Park PW, Conneely OM. Stimulus-dependent impairment of the neutrophil oxidative burst response in lactoferrin-deficient mice. Am J Pathol 2008;172:1019-29. [PubMed: 18321995]

92. Longhi C, Conte MP, Penta M, Cossu A, Antonini G, Superti F, et al. Lactoferricin influences early events of Listeria monocytogenes infection in THP-1 human macrophages. J Med Microbiol 2004;53:87-91. [PubMed: 14729926]

93. Wakabayashi H, Takakura N, Teraguchi S, Tamura Y. Lactoferrin feeding augments peritoneal macrophage activities in mice intraperitoneally injected with inactivated Candida albicans. Microbiol Immunol 2003;47:37-43. [PubMed: 12636251]

94. Sorimachi K, Akimoto K, Hattori Y, Ieiri T, Niwa A. Activation of macrophages by lactoferrin: secretion of TNF-alpha, IL-8 and NO. Biochem Mol Biol Int 1997;43:79-87. [PubMed: 9315285]

95. Na YJ, Han SB, Kang JS, Yoon YD, Park SK, Kim HM, et al. Lactoferrin works as a new LPSbinding protein in inflammatory activation of macrophages. Int Immunopharmacol 2004;4:118799. [PubMed: 15251114]

96. Puddu P, Carollo MG, Belardelli F, Valenti P, Gessani S. Role of endogenous interferon and LPS in the immunomodulatory effects of bovine lactoferrin in murine peritoneal macrophages. J Leukoc Biol 2007;82:347-53. [PubMed: 17475783]

97. Suzuki YA, Lopez V, Lonnerdal B. Mammalian lactoferrin receptors: structure and function. Cell Mol Life Sci 2005;62:2560-75. [PubMed: 16261254]

98. Mincheva-Nilsson L, Hammarstrom S, Hammarstrom ML. Activated human gamma delta T lymphocytes express functional lactoferrin receptors. Scand J Immunol 1997;46:609-18. [PubMed: 9420625]

99. Hammarstrom ML, Mincheva-Nilsson L, Hammarstrom S. Functional lactoferrin receptors on activated human lymphocytes. Adv Exp Med Biol 1995;371A:47-53. [PubMed: 8525969]

100. Birgens HS. The monocytic receptor for lactoferrin and its involvement in lactoferrin-mediated iron transport. Adv Exp Med Biol 1994;357:99-109. [PubMed: 7762450]

101. Iyer S, Lonnerdal B. Lactoferrin, lactoferrin receptors and iron metabolism. Eur J Clin Nutr 1993;47:232-41. [PubMed: 8491159]

102. Groot F, Geijtenbeek TB, Sanders RW, Baldwin CE, Sanchez-Hernandez M, Floris R, et al. Lactoferrin prevents dendritic cell-mediated human immunodeficiency virus type 1 transmission by blocking the DC-SIGN--gp120 interaction. J Virol 2005;79:3009-15. [PubMed: 15709021]

103. Zimecki M, Wlaszczyk A, Wojciechowski R, Dawiskiba J, Kruzel M. Lactoferrin regulates the immune responses in post-surgical patients. Arch Immunol Ther Exp (Warsz) 2001;49:325-33. [PubMed: 11726036]

104. Machnicki M, Zimecki M, Zagulski T. Lactoferrin regulates the release of tumour necrosis factor alpha and interleukin 6 in vivo. Int J Exp Pathol 1993;74:433-9. [PubMed: 8217778]

105. Zimecki M, Dawiskiba J, Zawirska B, Krawczyk Z, Kruzel M. Bovine lactoferrin decreases histopathological changes in the liver and regulates cytokine production by splenocytes of obstructive jaundiced rats. Inflamm Res 2003;52:305-10. [PubMed: 12861396]

106. Haversen L, Ohlsson BG, Hahn-Zoric M, Hanson LA, Mattsby-Baltzer I. Lactoferrin downregulates the LPS-induced cytokine production in monocytic cells via NF-kappa B. Cell Immunol 2002;220:83-95. [PubMed: 12657243]

107. Wakabayashi H, Kurokawa M, Shin K, Teraguchi S, Tamura Y, Shiraki K. Oral lactoferrin prevents body weight loss and increases cytokine responses during herpes simplex virus type 1 infection of mice. Biosci Biotechnol Biochem 2004;68:537-44. [PubMed: 15056884]

108. Wakabayashi H, Takakura N, Yamauchi K, Tamura Y. Modulation of immunity-related gene expression in small intestines of mice by oral administration of lactoferrin. Clin Vaccine Immunol 2006;13:239-45. [PubMed: 16467332]

109. Teraguchi S, Wakabayashi H, Kuwata H, Yamauchi K, Tamura Y. Protection against infections by oral lactoferrin: evaluation in animal models. Biometals 2004;17:231-4. [PubMed: 15222470]

110. Hwang SA, Wilk KM, Bangale YA, Kruzel ML, Actor JK. Lactoferrin modulation of IL-12 and IL-10 response from activated murine leukocytes. Med Microbiol Immunol 2007;196:171-80. [PubMed: 17377816] 
111. Wilk KM, Hwang SA, Actor JK. Lactoferrin modulation of antigen-presenting-cell response to BCG infection. Postepy Hig Med Dosw (Online) 2007;61:277-82. [PubMed: 17507876]

112. Trinchieri G. Interleukin-12 and the regulation of innate resistance and adaptive immunity. Nat Rev Immunol 2003;3:133-46. [PubMed: 12563297]

113. Trinchieri G. Interleukin-12: a proinflammatory cytokine with immunoregulatory functions that bridge innate resistance and antigen-specific adaptive immunity. Annu Rev Immunol 1995;13:251-76. [PubMed: 7612223]

114. Puddu P, Valenti P, Gessani S. Immunomodulatory effects of lactoferrin on antigen presenting cells. Biochimie. 2008

115. Roseanu A, Chelu F, Trif M, Motas C, Brock JH. Inhibition of binding of lactoferrin to the human promonocyte cell line THP-1 by heparin: the role of cell surface sulphated molecules. Biochim Biophys Acta 2000;1475:35-8. [PubMed: 10806335]

116. Britigan BE, Serody JS, Hayek MB, Charniga LM, Cohen MS. Uptake of lactoferrin by mononuclear phagocytes inhibits their ability to form hydroxyl radical and protects them from membrane autoperoxidation. J Immunol 1991;147:4271-7. [PubMed: 1661314]

117. Tanida T, Rao F, Hamada T, Ueta E, Osaki T. Lactoferrin peptide increases the survival of Candida albicansinoculated mice by upregulating neutrophil and macrophage functions, especially in combination with amphotericin B and granulocyte-macrophage colony-stimulating factor. Infect Immun 2001;69:3883-90. [PubMed: 11349055]

118. Zimecki M, Machnicki M. Lactoferrin inhibits the effector phase of the delayed type hypersensitivity to sheep erythrocytes and inflammatory reactions to M. bovis (BCG). Arch Immunol Ther Exp (Warsz) 1994;42:171-7. [PubMed: 7487348]

119. Hwang SA, Kruzel ML, Actor JK. Influence of bovine lactoferrin on expression of presentation molecules on BCG-infected bone marrow derived macrophages. Biochimie 2009;91:76-85. [PubMed: 18486627]

120. Curran CS, Demick KP, Mansfield JM. Lactoferrin activates macrophages via TLR4-dependent and -independent signaling pathways. Cell Immunol 2006;242:23-30. [PubMed: 17034774]

121. Bhatia S, Edidin M, Almo SC, Nathenson SG. B7-1 and B7-2: similar costimulatory ligands with different biochemical, oligomeric and signaling properties. Immunol Lett 2006;104:70-5. [PubMed: 16413062]

122. Pentcheva-Hoang T, Egen JG, Wojnoonski K, Allison JP. B7-1 and B7-2 selectively recruit CTLA-4 and CD28 to the immunological synapse. Immunity 2004;21:401-13. [PubMed: 15357951]

123. Seder RA, Gazzinelli R, Sher A, Paul WE. Interleukin 12 acts directly on CD4+ T cells to enhance priming for interferon gamma production and diminishes interleukin 4 inhibition of such priming. Proc Natl Acad Sci U S A 1993;90:10188-92. [PubMed: 7901851]

124. Schmitt E, Hoehn P, Huels C, Goedert S, Palm N, Rude E, et al. T helper type 1 development of naive CD4+ T cells requires the coordinate action of interleukin-12 and interferon-gamma and is inhibited by transforming growth factor-beta. Eur J Immunol 1994;24:793-8. [PubMed: 7908633]

125. Murphy EE, Terres G, Macatonia SE, Hsieh CS, Mattson J, Lanier L, et al. B7 and interleukin 12 cooperate for proliferation and interferon gamma production by mouse $\mathrm{T}$ helper clones that are unresponsive to B7 costimulation. J Exp Med 1994;180:223-31. [PubMed: 7516409]

126. Gately MK, Renzetti LM, Magram J, Stern AS, Adorini L, Gubler U, et al. The interleukin-12/ interleukin-12-receptor system: role in normal and pathologic immune responses. Annu Rev Immunol 1998;16:495-521. [PubMed: 9597139]

127. Iigo M, Shimamura M, Matsuda E, Fujita K, Nomoto H, Satoh J, et al. Orally administered bovine lactoferrin induces caspase-1 and interleukin-18 in the mouse intestinal mucosa: a possible explanation for inhibition of carcinogenesis and metastasis. Cytokine 2004;25:36-44. [PubMed: 14687584]

128. Reddy P. Interleukin-18: recent advances. Curr Opin Hematol 2004;11:405-10. [PubMed: 15548995]

129. Martinon F, Tschopp J. Inflammatory caspases and inflammasomes: master switches of inflammation. Cell Death Differ 2007;14:10-22. [PubMed: 16977329] 
130. Murphy KM, Reiner SL. The lineage decisions of helper T cells. Nat Rev Immunol 2002;2:93344. [PubMed: 12461566]

131. Ahmadzadeh M, Farber DL. Functional plasticity of an antigen-specific memory CD4 T cell population. Proc Natl Acad Sci U S A 2002;99:11802-7. [PubMed: 12192093]

132. Radhakrishnan S, Wiehagen KR, Pulko V, Van Keulen V, Faubion WA, Knutson KL, et al. Induction of a Th1 response from Th2-polarized T cells by activated dendritic cells: dependence on TCR: peptide-MHC interaction, ICAM-1, IL-12, and IFN-gamma. J Immunol 2007;178:3583-92. [PubMed: 17339455]

133. Saidi H, Eslahpazir J, Carbonneil C, Carthagena L, Requena M, Nassreddine N, et al. Differential modulation of human lactoferrin activity against both R5 and X4-HIV-1 adsorption on epithelial cells and dendritic cells by natural antibodies. J Immunol 2006;177:5540-9. [PubMed: 17015741]

134. Cumberbatch M, Dearman RJ, Uribe-Luna S, Headon DR, Ward PP, Conneely OM, et al. Regulation of epidermal Langerhans cell migration by lactoferrin. Immunology 2000;100:21-8. [PubMed: 10809955]

135. Cumberbatch M, Bhushan M, Dearman RJ, Kimber I, Griffiths CE. IL-1beta-induced Langerhans' cell migration and TNF-alpha production in human skin: regulation by lactoferrin. Clin Exp Immunol 2003;132:352-9. [PubMed: 12699428]

136. Griffiths CE, Cumberbatch M, Tucker SC, Dearman RJ, Andrew S, Headon DR, et al. Exogenous topical lactoferrin inhibits allergen-induced Langerhans cell migration and cutaneous inflammation in humans. Br J Dermatol 2001;144:715-25. [PubMed: 11298528]

137. Kimber I, Cumberbatch M, Dearman RJ, Headon DR, Bhushan M, Griffiths CE. Lactoferrin: influences on Langerhans cells, epidermal cytokines, and cutaneous inflammation. Biochem Cell Biol 2002;80:103-7. [PubMed: 11911118]

138. Mikkelsen TL, Bakman S, Sorensen ES, Barkholt V, Frokiaer H. Sialic acid-containing milk proteins show differential immunomodulatory activities independent of sialic acid. J Agric Food Chem 2005;53:7673-80. [PubMed: 16190615]

139. Toebak MJ, de Rooij J, Moed H, Stoof TJ, von Blomberg BM, Bruynzeel DP, et al. Differential suppression of dendritic cell cytokine production by anti-inflammatory drugs. Br J Dermatol 2008;158:225-33. [PubMed: 18028503]

140. Spadaro M, Caorsi C, Ceruti P, Varadhachary A, Forni G, Pericle F, et al. Lactoferrin, a major defense protein of innate immunity, is a novel maturation factor for human dendritic cells. Faseb J. 2008

141. Kaiko GE, Horvat JC, Beagley KW, Hansbro PM. Immunological decision-making: how does the immune system decide to mount a helper T-cell response? Immunology 2008;123:326-38. [PubMed: 17983439]

142. Constant SL, Bottomly K. Induction of Th1 and Th2 CD4+ T cell responses: the alternative approaches. Annu Rev Immunol 1997;15:297-322. [PubMed: 9143690]

143. Sanders VM. Epigenetic regulation of Th1 and Th2 cell development. Brain Behav Immun 2006;20:317-24. [PubMed: 16226007]

144. Tanaka T, Morita H, Yoo YC, Kim WS, Kumura H, Shimazaki K. Detection of bovine lactoferrin binding protein on Jurkat human lymphoblastic T cell line. J Vet Med Sci 2004;66:865-9. [PubMed: 15297761]

145. Legrand D, van Berkel PH, Salmon V, van Veen HA, Slomianny MC, Nuijens JH, et al. The Nterminal Arg2, Arg3 and Arg4 of human lactoferrin interact with sulphated molecules but not with the receptor present on Jurkat human lymphoblastic T-cells. Biochem J 1997;327 (Pt 3): 841-6. [PubMed: 9581564]

146. Bi BY, Liu JL, Legrand D, Roche AC, Capron M, Spik G, et al. Internalization of human lactoferrin by the Jurkat human lymphoblastic T-cell line. Eur J Cell Biol 1996;69:288-96. [PubMed: 8900493]

147. Dhennin-Duthille I, Masson M, Damiens E, Fillebeen C, Spik G, Mazurier J. Lactoferrin upregulates the expression of CD4 antigen through the stimulation of the mitogen-activated protein kinase in the human lymphoblastic T Jurkat cell line. J Cell Biochem 2000;79:583-93. [PubMed: 10996849] 
148. Frydecka I, Zimecki M, Bocko D, Kosmaczewska A, Teodorowska R, Ciszak L, et al. Lactoferrin-induced up-regulation of zeta (zeta) chain expression in peripheral blood T lymphocytes from cervical cancer patients. Anticancer Res 2002;22:1897-901. [PubMed: 12168890]

149. Zimecki M, Stepniak D, Szynol A, Kruzel ML. Lactoferrin regulates proliferative response of human peripheral blood mononuclear cells to phytohemagglutinin and mixed lymphocyte reaction. Arch Immunol Ther Exp (Warsz) 2001;49:147-54. [PubMed: 11348019]

150. Kobayashi S, Sato R, Inanami O, Yamamori T, Yamato O, Maede Y, et al. Reduction of concanavalin A-induced expression of interferon-gamma by bovine lactoferrin in feline peripheral blood mononuclear cells. Vet Immunol Immunopathol 2005;105:75-84. [PubMed: 15797477]

151. Moed H, Stoof TJ, Boorsma DM, von Blomberg BM, Gibbs S, Bruynzeel DP, et al. Identification of anti-inflammatory drugs according to their capacity to suppress type- 1 and type-2 T cell profiles. Clin Exp Allergy 2004;34:1868-75. [PubMed: 15663561]

152. Kocieba M, Zimecki M, Kruzel M, Actor J. The adjuvant activity of lactoferrin in the generation of DTH to ovalbumin can be inhibited by bovine serum albumin bearing alpha-Dmannopyranosyl residues. Cell Mol Biol Lett 2002;7:1131-6. [PubMed: 12511980]

153. Zimecki M, Kruzel ML. Systemic or local co-administration of lactoferrin with sensitizing dose of antigen enhances delayed type hypersensitivity in mice. Immunol Lett 2000;74:183-8. [PubMed: 11064098]

154. Artym J, Zimecki M, Kruzel ML. Reconstitution of the cellular immune response by lactoferrin in cyclophosphamide-treated mice is correlated with renewal of T cell compartment. Immunobiology 2003;207:197-205. [PubMed: 12777061]

155. Artym J, Zimecki M, Paprocka M, Kruzel ML. Orally administered lactoferrin restores humoral immune response in immunocompromised mice. Immunol Lett 2003;89:9-15. [PubMed: 12946859]

156. Artym J, Zimecki M, Kuryszko J, Kruzel ML. Lactoferrin accelerates reconstitution of the humoral and cellular immune response during chemotherapy-induced immunosuppression and bone marrow transplant in mice. Stem Cells Dev 2005;14:548-55. [PubMed: 16305339]

157. Kruzel, M.; Artym, J.; Chodaczek, G.; Kocieba, M.; Kochanowska, I.; Kruzel, T., et al. Effects of lactoferrin on stress-related immune dysfunctions in mice and humans. 4th International Whey Conference; Chicago, IL. 2005. p. 121-32.

158. Wang WP, Iigo M, Sato J, Sekine K, Adachi I, Tsuda H. Activation of intestinal mucosal immunity in tumor-bearing mice by lactoferrin. Jpn J Cancer Res 2000;91:1022-7. [PubMed: 11050473]

159. Sfeir RM, Dubarry M, Boyaka PN, Rautureau M, Tome D. The mode of oral bovine lactoferrin administration influences mucosal and systemic immune responses in mice. J Nutr 2004;134:403-9. [PubMed: 14747680]

160. Li KJ, Lu MC, Hsieh SC, Wu CH, Yu HS, Tsai CY, et al. Release of surface-expressed lactoferrin from polymorphonuclear neutrophils after contact with CD4+ T cells and its modulation on Th1/Th2 cytokine production. J Leukoc Biol 2006;80:350-8. [PubMed: 16769765]

161. Fischer R, Debbabi H, Dubarry M, Boyaka P, Tome D. Regulation of physiological and pathological Th1 and Th2 responses by lactoferrin. Biochem Cell Biol 2006;84:303-11. [PubMed: 16936801]

162. Mosmann TR, Coffman RL. Heterogeneity of cytokine secretion patterns and functions of helper T cells. Adv Immunol 1989;46:111-47. [PubMed: 2528896]

163. Zimecki M, Mazurier J, Spik G, Kapp JA. Lactoferrin inhibits proliferative response and cytokine production of TH1 but not TH2 cell lines. Arch Immunol Ther Exp (Warsz) 1996;44:51-6. [PubMed: 8874770]

164. Takakura N, Wakabayashi H, Yamauchi K, Takase M. Influences of orally administered lactoferrin on IFN-gamma and IL-10 production by intestinal intraepithelial lymphocytes and mesenteric lymph-node cells. Biochem Cell Biol 2006;84:363-8. [PubMed: 16936808] 
165. Guillen C, McInnes IB, Vaughan DM, Kommajosyula S, Van Berkel PH, Leung BP, et al. Enhanced Th1 response to Staphylococcus aureus infection in human lactoferrin-transgenic mice. J Immunol 2002;168:3950-7. [PubMed: 11937551]

166. Hwang SA, Kruzel ML, Actor JK. Lactoferrin augments BCG vaccine efficacy to generate T helper response and subsequent protection against challenge with virulent Mycobacterium tuberculosis. Int Immunopharmacol 2005;5:591-9. [PubMed: 15683854]

167. Hwang SA, Wilk KM, Budnicka M, Olsen M, Bangale YA, Hunter RL, et al. Lactoferrin enhanced efficacy of the BCG vaccine to generate host protective responses against challenge with virulent Mycobacterium tuberculosis. Vaccine 2007;25:6730-43. [PubMed: 17698261]

168. Debbabi H, Dubarry M, Rautureau M, Tome D. Bovine lactoferrin induces both mucosal and systemic immune response in mice. J Dairy Res 1998;65:283-293. [PubMed: 9627847]

169. Artym J, Zimecki M, Kruzel ML. Effect of lactoferrin on the methotrexate-induced suppression of the cellular and humoral immune response in mice. Anticancer Res 2004;24:3831-6. [PubMed: 15736418]

170. Choi BK, Actor JK, Rios S, d'Anjou M, Stadheim TA, Warburton S, et al. Recombinant human lactoferrin expressed in glycoengineered Pichia pastoris: effect of terminal N-acetylneuraminic acid on in vitro secondary humoral immune response. Glycoconj J 2008;25:581-93. [PubMed: 18365311]

171. Kumari J, Sahoo PK. Dietary immunostimulants influence specific immune response and resistance of healthy and immunocompromised Asian catfish Clarias batrachus to Aeromonas hydrophila infection. Dis Aquat Organ 2006;70:63-70. [PubMed: 16875392]

172. Kamilya D, Maiti TK, Joardar SN, Mal BC. Adjuvant effect of mushroom glucan and bovine lactoferrin upon Aeromonas hydrophila vaccination in catla, Catla catla (Hamilton). J Fish Dis 2006;29:331-7. [PubMed: 16768713]

173. Chodaczek G, Zimecki M, Lukasiewicz J, Lugowski C. A complex of lactoferrin with monophosphoryl lipid A is an efficient adjuvant of the humoral and cellular immune response in mice. Med Microbiol Immunol 2006;195:207-16. [PubMed: 16838169]

174. Chodaczek G, Zimecki M, Lukasiewicz J, Lugowski C. Lactoferrin-monophosphoryl lipid a complex enhances immunity of mice to Plesiomonas shigelloides CNCTC 138/92. Acta Biochim Pol 2008;55:91-6. [PubMed: 18231655]

175. Thotathil Z, Jameson MB. Early experience with novel immunomodulators for cancer treatment. Expert Opin Investig Drugs 2007;16:1391-403.

176. Lin TY, Chu C, Chiu CH. Lactoferrin inhibits enterovirus 71 infection of human embryonal rhabdomyosarcoma cells in vitro. J Infect Dis 2002;186:1161-4. [PubMed: 12355368]

177. Bayes M, Rabasseda X, Prous JR. Gateways to clinical trials. Methods Find Exp Clin Pharmacol 2004;26:473-503. [PubMed: 15349141]

178. Portielje JE, Kruit WH, Eerenberg AJ, Schuler M, Sparreboom A, Lamers CH, et al. Subcutaneous injection of interleukin 12 induces systemic inflammatory responses in humans: implications for the use of IL-12 as vaccine adjuvant. Cancer Immunol Immunother 2005;54:3743. [PubMed: 15693137]

179. Stewart-Tull DE, Bleakley CR, Galloway TS. Characteristics of Vibrio cholerae proteinases: potential, candidate vaccine antigens. Vaccine 2004;22:3026-34. [PubMed: 15297052]

180. Cox TM, Mazurier J, Spik G, Montreuil J, Peters TJ. Iron binding proteins and influx of iron across the duodenal brush border. Evidence for specific lactotransferrin receptors in the human intestine. Biochim Biophys Acta 1979;588:120-8. [PubMed: 227471]

181. Lopez V, Suzuki YA, Lonnerdal B. Ontogenic changes in lactoferrin receptor and DMT1 in mouse small intestine: implications for iron absorption during early life. Biochem Cell Biol 2006;84:337-44. [PubMed: 16936804]

182. Van Snick JL, Masson PL. The binding of human lactoferrin to mouse peritoneal cells. J Exp Med 1976;144:1568-80. [PubMed: 1003104]

183. Legrand D, Elass E, Carpentier M, Mazurier J. Interactions of lactoferrin with cells involved in immune function. Biochem Cell Biol 2006;84:282-90. [PubMed: 16936798]

184. Mazurier J, Montreuil J, Spik G. Visualization of lactotransferrin brush-border receptors by ligand-blotting. Biochim Biophys Acta 1985;821:453-60. [PubMed: 3000447] 
185. Leveugle B, Mazurier J, Legrand D, Mazurier C, Montreuil J, Spik G. Lactotransferrin binding to its platelet receptor inhibits platelet aggregation. Eur J Biochem 1993;213:1205-11. [PubMed: 8389297]

186. Grey A, Banovic T, Zhu Q, Watson M, Callon K, Palmano K, et al. The low-density lipoprotein receptor-related protein 1 is a mitogenic receptor for lactoferrin in osteoblastic cells. Mol Endocrinol 2004;18:2268-78. [PubMed: 15178744]

187. Mazurier J, Legrand D, Hu WL, Montreuil J, Spik G. Expression of human lactotransferrin receptors in phytohemagglutinin-stimulated human peripheral blood lymphocytes. Isolation of the receptors by antiligand-affinity chromatography. Eur J Biochem 1989;179:481-7. [PubMed: 2537213]

188. Birgens HS, Hansen NE, Karle H, Kristensen LO. Receptor binding of lactoferrin by human monocytes. Br J Haematol 1983;54:383-91. [PubMed: 6305392]

189. Bennett RM, Davis J. Lactoferrin binding to human peripheral blood cells: an interaction with a B-enriched population of lymphocytes and a subpopulation of adherent mononuclear cells. J Immunol 1981;127:1211-6. [PubMed: 6973582]

190. van Snick JL, Markowetz B, Masson PL. The ingestion and digestion of human lactoferrin by mouse peritoneal macrophages and the transfer of its iron into ferritin. J Exp Med 1977;146:81727. [PubMed: 894189]

191. Huang RQ, Ke WL, Qu YH, Zhu JH, Pei YY, Jiang C. Characterization of lactoferrin receptor in brain endothelial capillary cells and mouse brain. J Biomed Sci 2007;14:121-8. [PubMed: 17048089]

192. Fillebeen C, Descamps L, Dehouck MP, Fenart L, Benaissa M, Spik G, et al. Receptor-mediated transcytosis of lactoferrin through the blood-brain barrier. J Biol Chem 1999;274:7011-7. [PubMed: 10066755]

193. McAbee DD, Nowatzke W, Oehler C, Sitaram M, Sbaschnig E, Opferman JT, et al. Endocytosis and degradation of bovine apo- and holo-lactoferrin by isolated rat hepatocytes are mediated by recycling calcium-dependent binding sites. Biochemistry 1993;32:13749-60. [PubMed: 8257710]

194. Lopez V, Kelleher SL, Lonnerdal B. Lactoferrin receptor mediates apo- but not holo-lactoferrin internalization via clathrin-mediated endocytosis in trophoblasts. Biochem J 2008;411:271-8.

195. Ammendolia MG, Marchetti M, Superti F. Bovine lactoferrin prevents the entry and intercellular spread of herpes simplex virus type 1 in Green Monkey Kidney cells. Antiviral Res 2007;76:252-62. [PubMed: 17881064]

196. Marchetti M, Trybala E, Superti F, Johansson M, Bergstrom T. Inhibition of herpes simplex virus infection by lactoferrin is dependent on interference with the virus binding to glycosaminoglycans. Virology 2004;318:405-13. [PubMed: 14972565]

197. Elass-Rochard E, Legrand D, Salmon V, Roseanu A, Trif M, Tobias PS, et al. Lactoferrin inhibits the endotoxin interaction with CD14 by competition with the lipopolysaccharide-binding protein. Infect Immun 1998;66:486-91. [PubMed: 9453600]

198. Baveye S, Elass E, Fernig DG, Blanquart C, Mazurier J, Legrand D. Human lactoferrin interacts with soluble CD14 and inhibits expression of endothelial adhesion molecules, E-selectin and ICAM-1, induced by the CD14-lipopolysaccharide complex. Infect Immun 2000;68:6519-25. [PubMed: 11083760]

199. Britigan BE, Lewis TS, Waldschmidt M, McCormick ML, Krieg AM. Lactoferrin binds CpGcontaining oligonucleotides and inhibits their immunostimulatory effects on human B cells. J Immunol 2001;167:2921-8. [PubMed: 11509640]

200. Mulligan P, White NR, Monteleone G, Wang P, Wilson JW, Ohtsuka Y, et al. Breast milk lactoferrin regulates gene expression by binding bacterial DNA CpG motifs but not genomic DNA promoters in model intestinal cells. Pediatr Res 2006;59:656-61. [PubMed: 16627877]

201. Choi BK, Actor JK, Rios S, d'Anjou M, Stadheim TA, Warburton S, et al. Recombinant human lactoferrin expressed in glycoengineered Pichia pastoris: effect of terminal $\mathrm{N}$-acetylneuraminic acid on in vitro secondary humoral immune response. Glycoconj J. 2008 
202. Spik G, Coddeville B, Mazurier J, Bourne Y, Cambillaut C, Montreuil J. Primary and threedimensional structure of lactotransferrin (lactoferrin) glycans. Adv Exp Med Biol 1994;357:2132. [PubMed: 7762433]

203. Elass E, Masson M, Mazurier J, Legrand D. Lactoferrin inhibits the lipopolysaccharide-induced expression and proteoglycan-binding ability of interleukin-8 in human endothelial cells. Infect Immun 2002;70:1860-6. [PubMed: 11895948]

204. Boldogh I, Roy G, Lee MS, Bacsi A, Hazra TK, Bhakat KK, et al. Reduced DNA double strand breaks in chlorambucil resistant cells are related to high DNA-PKcs activity and low oxidative stress. Toxicology 2003;193:137-52. [PubMed: 14599773] 

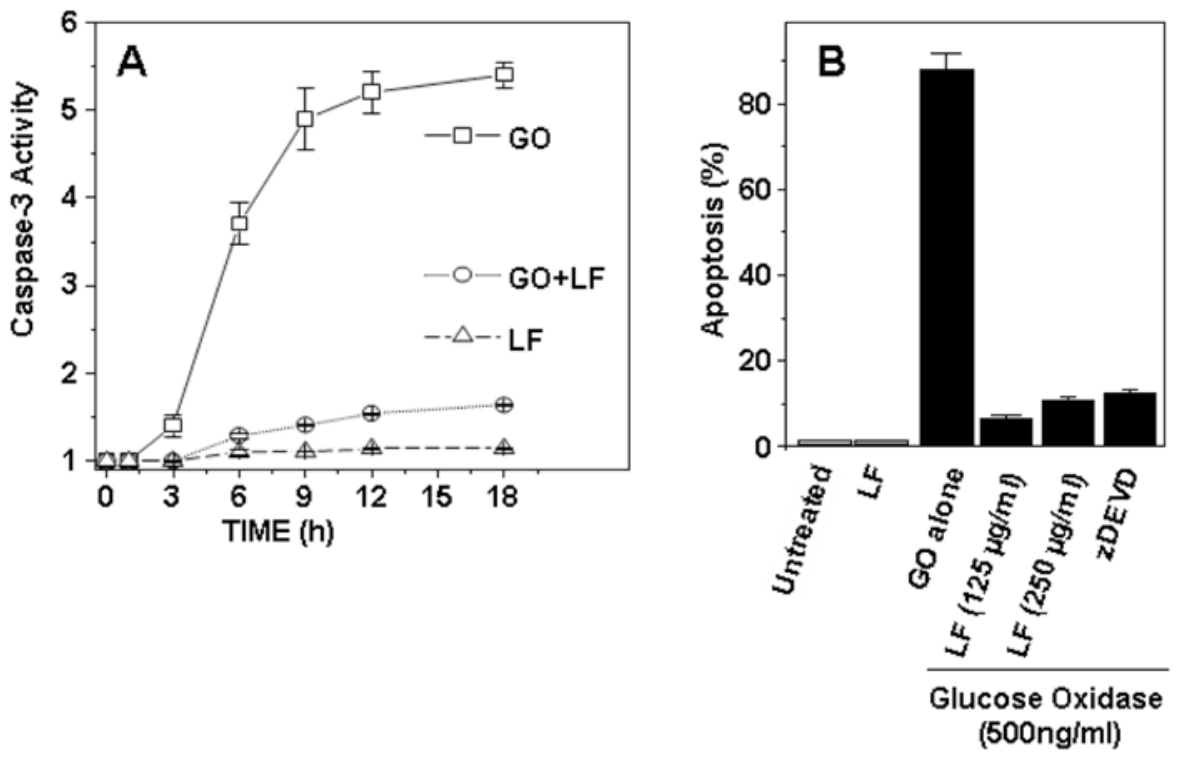

Fig. 1. LF inhibits oxidative stress-induced apoptosis Lactoferrin was assessed for activity to limit apoptosis as defined by activation of caspase-3 (A) or Annexin V presentation (B). U937 cell pellets were examined post-treatment with glucose oxidase (GO, $500 \mathrm{ng} / \mathrm{mL}$ ), with or without lactoferrin (LF). Enzymatic reactions were performed with appropriate caspase substrate [45]. Caspase activity was determined by measuring the change in absorbance at $405 \mathrm{~nm}(\mathbf{A})$. Alternatively, cells were treated with GO alone or in the presence of lactoferrin $(125$ or $250 \mu \mathrm{g} / \mathrm{mL}$ ) or with z-DEVD-fmk (Nbenzyloxycarbonyl-Asp(OMe)-Glu(OMe)-Val-Asp(OMe)-fluoro-methylketone) a caspase3 inhibitor of GO-induced Annexin V binding (B). Cells were then stained with Annexin VFITC as described [204]. The mean fluorescence for 12,000 cells from three or more independent experiments are shown, expressed as \pm SEM. 


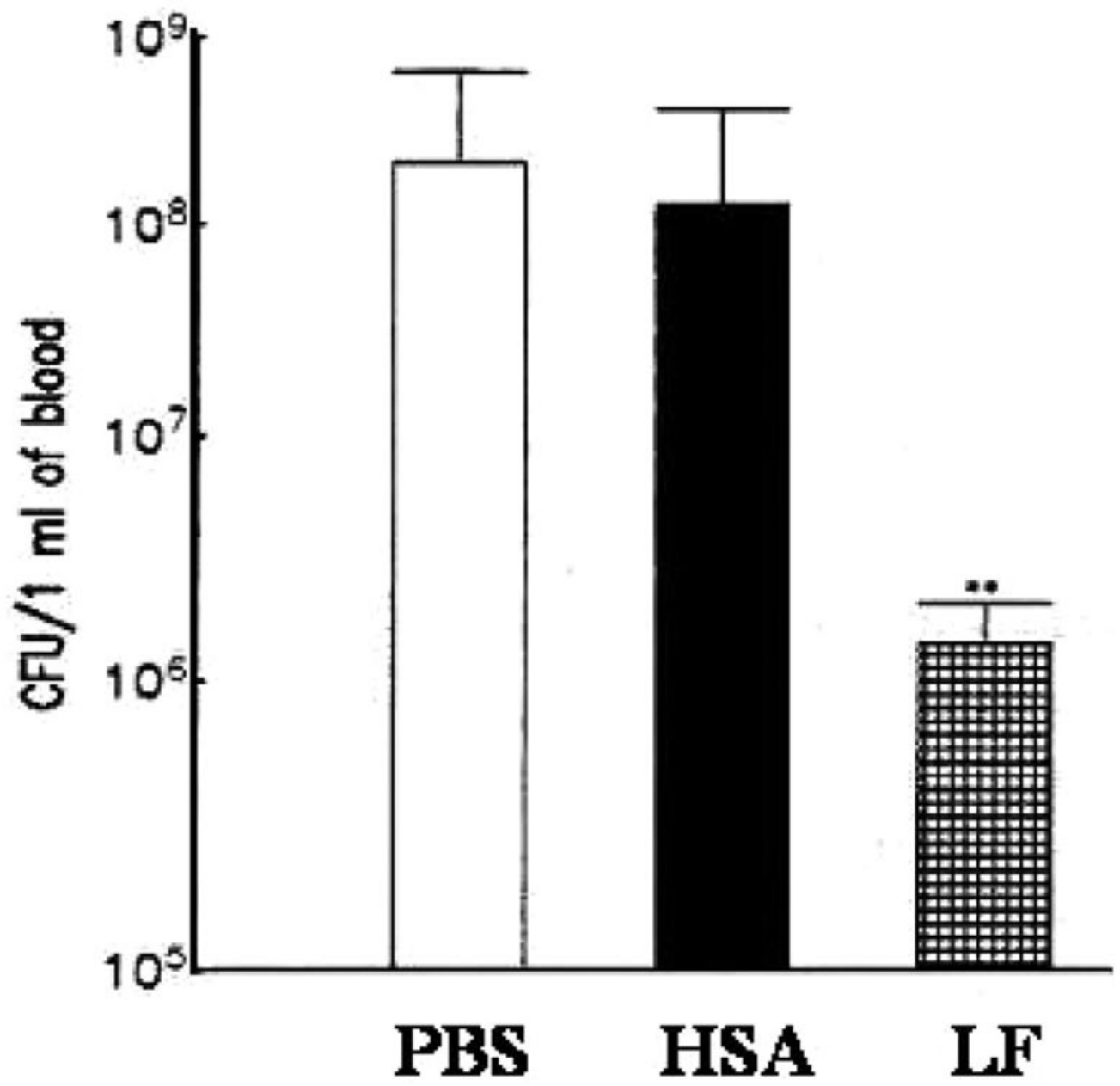

Fig. 2. Effect of lactoferrin on clearance of $E$. coli from circulation

Mice were challenged with a lethal dose of enterogenic bacteria $\left(2 \times 10^{8}\right.$ organisms, intravenous injection). The level of organisms within whole blood was measured $5 \mathrm{~h}$ post infection. Treatment of mice with LF (10 mg/mouse) $24 \mathrm{~h}$ prior to E. coli challenge (Lethal Dose, $\mathrm{LD}_{100}$ ) resulted in 100 fold faster clearing of bacteria from circulation, when compared with controls. E. coli + PBS (phosphate buffered saline, open); HSA (human serum albumin, closed); LF (lactoferrin, hatched). $* * p<0.05$ 


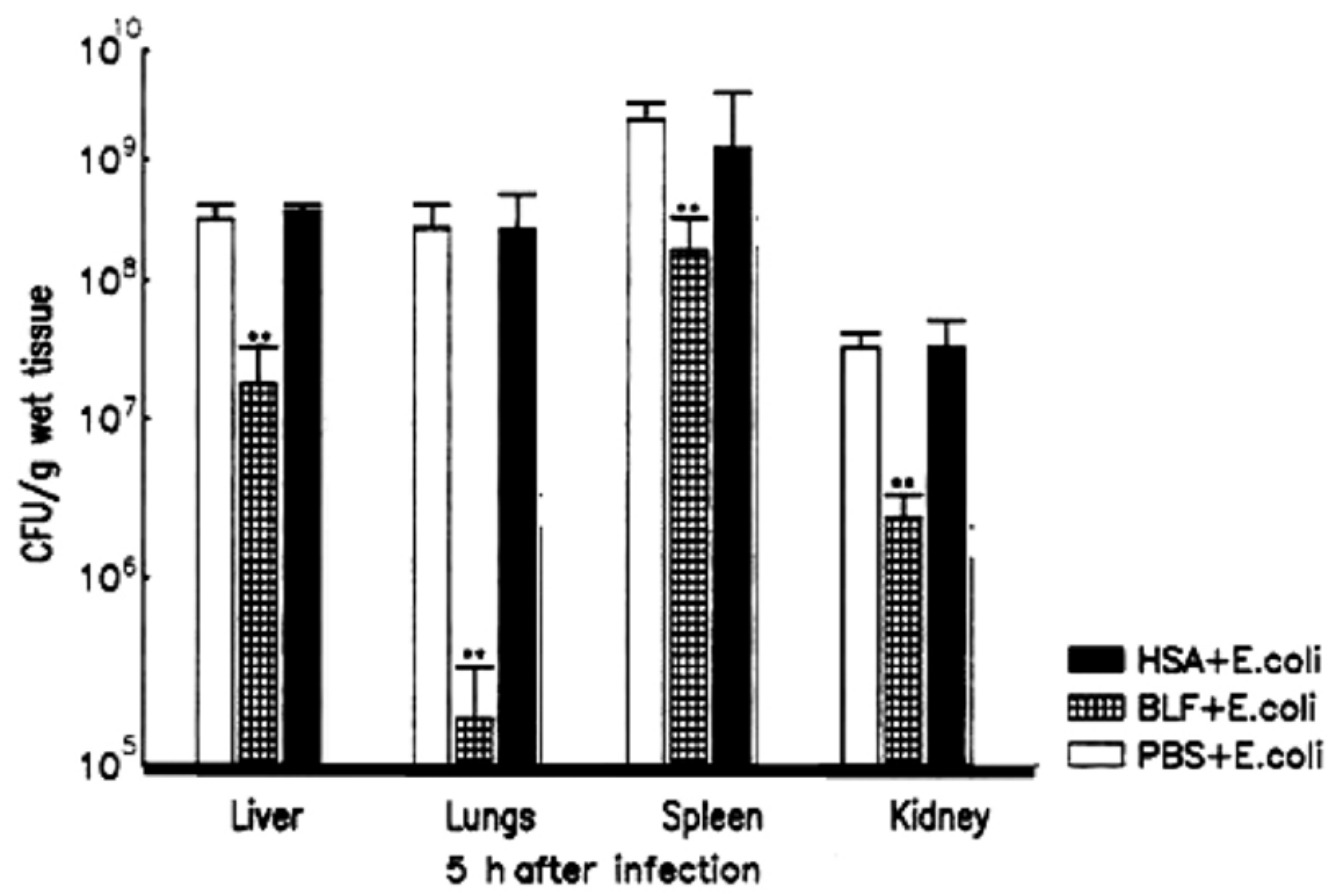

Fig. 3. Effect of lactoferrin on the clearance of $E$. coli from various organs Mice were challenged with a lethal dose of enterogenic bacteria $\left(2 \times 10^{8}\right.$ organisms, intravenous injection). Number of organisms was measured in lungs, spleens, livers and kidneys $5 \mathrm{~h}$ post infection. Treatment with $\mathrm{LF}(10 \mathrm{mg} / \mathrm{mouse}) 24 \mathrm{~h}$ prior to $E$. coli challenge $\left(\mathrm{LD}_{100}\right)$ decreased the number of organisms recovered in spleens, livers and kidneys over 10 fold, and in lungs over 1000 fold, when compared with PBS and/or HSA controls. ${ }^{* *} p<0.05$. 

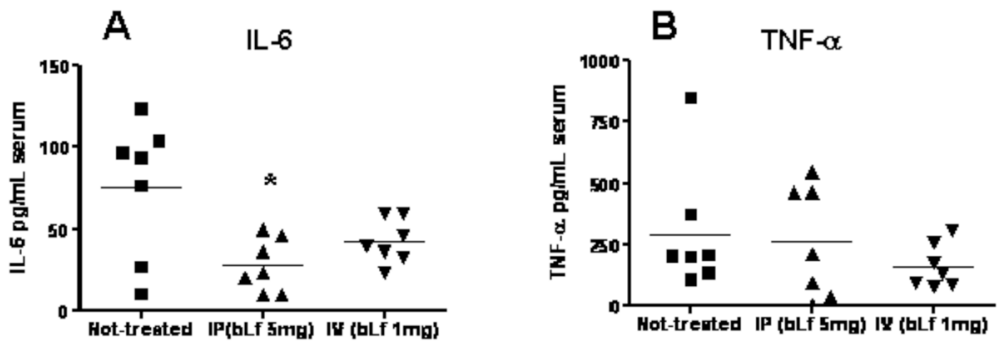

Fig. 4. Bovine lactoferrin pre-treatment leads to decreased proinflammatory responses from mice infected with E.coli

$\mathrm{BALB} / \mathrm{c}$ mice were pre-treated with bovine lactoferrin at $1 \mathrm{mg} / \mathrm{mouse}$ (intravenous) or $5 \mathrm{mg}$ / mouse (intraperitoneal) or remained untreated controls. After $4 \mathrm{~h}$, mice were infected with a sub-lethal dose $\left(\sim 5 \times 10^{8} \mathrm{CFU} / \mathrm{mouse}\right)$ of E.coli SM105 (intravenous). At day 4 postinfection, blood was collected for analysis of cytokine production of IL-6 (A) and TNF- $\alpha$ (B) by ELISA. $* p<0.05$ compared to the control group not treated with lactoferrin. 
E.

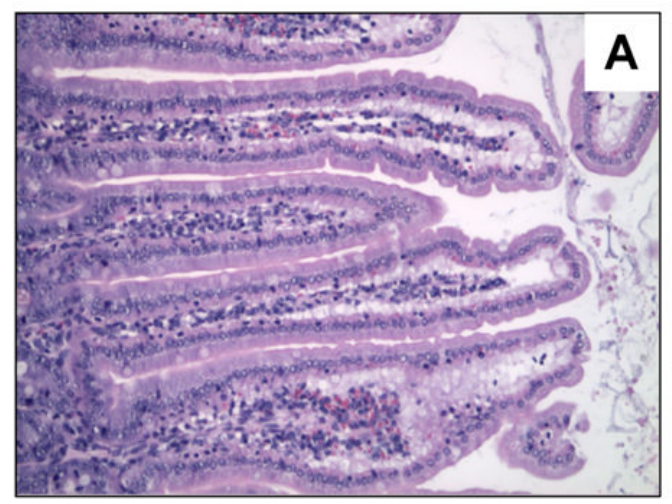

E. coli +

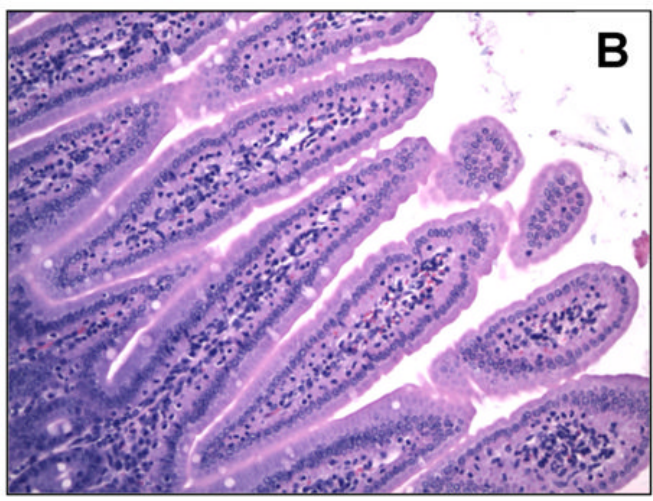

Fig. 5. Lactoferrin pre-treatment protects host gut integrity against sub-lethal challenge with $E$. coli

$\mathrm{BALB} / \mathrm{c}$ mice challenged with a sub-lethal dose of E.coli SM105 demonstrate severe jejunal tissue destruction at 4 days post infection (A). Parenchyma from mice pretreated with lactoferrin ( $1 \mathrm{mg} / \mathrm{mouse}$, intravenous, 4 hours prior to challenge) remained intact $(\mathbf{B})$, with no demonstration of tissue damage Jejunal tissue was collected and fixed with $10 \%$ formalin, paraffin embedded, sectioned, and stained with H\&E. Visualized at 100×. 
A

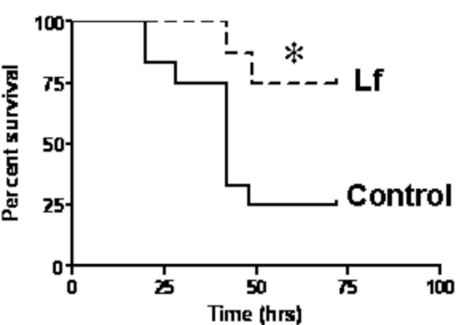

C

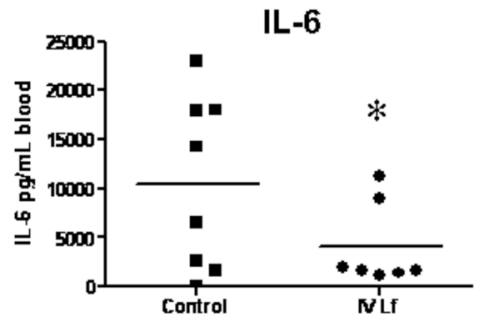

B

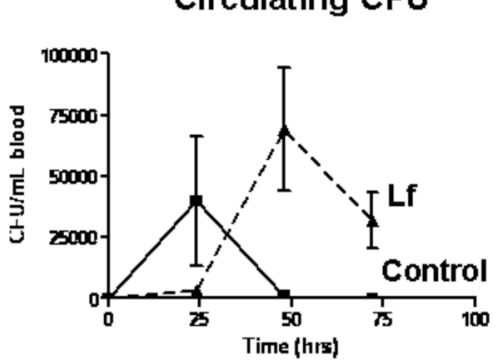

D

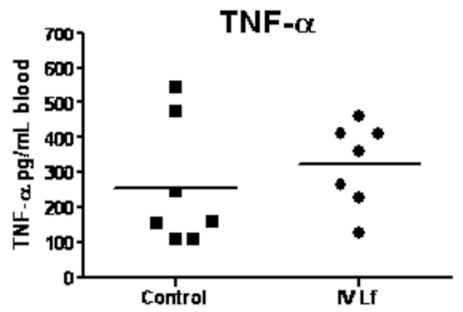

Fig. 6. Effect of lactoferrin on host protection against MRSA infection

$\mathrm{BALB} / \mathrm{c}$ mice were pre-treated with bovine lactoferrin (1 mg/mouse, intravenous) or remain untreated. After $2 \mathrm{~h}$, mice were infected with MRSA (strain Mu50, American Type Tissue Culture, intaperitoneal, $1 \times 10^{9} \mathrm{CFU} /$ mouse). Mice were monitored for survival (A). At various time points, blood was collected for analysis of bacterial load (B) and cytokine production $(\mathbf{C , D})$ by ELISA. * $p<0.05$ compared to the no lactoferrin control group. 

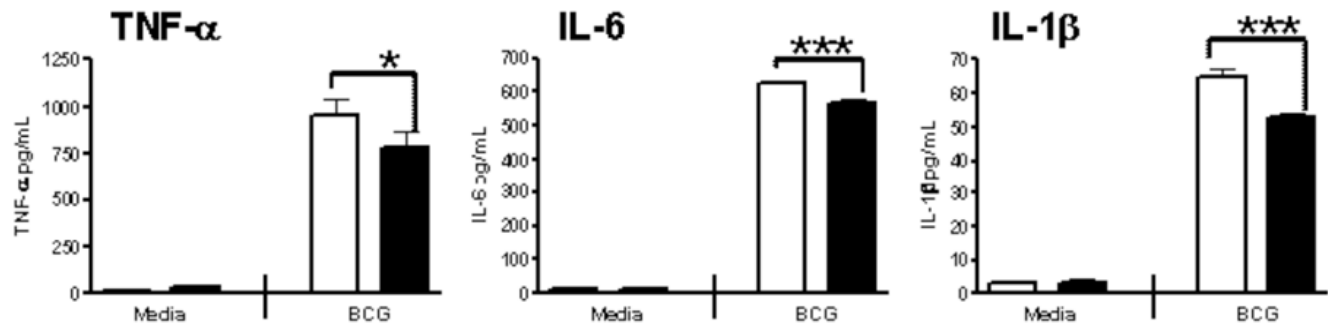

Fig. 7. Lactoferrin decreases proinflammatory cytokines from BCG infected macrophages Bone marrow derived macrophages were infected with BCG (MOI 10: 1) without (white) or with (black) bovine lactoferrin $(100 \mu \mathrm{g} / \mathrm{mL})$. At $72 \mathrm{~h}$, supernatants were collected and analyzed by ELISA for TNF- $\alpha$, IL-6, and IL- $1 \beta . * p<0.05, * * * p<0.001$. 

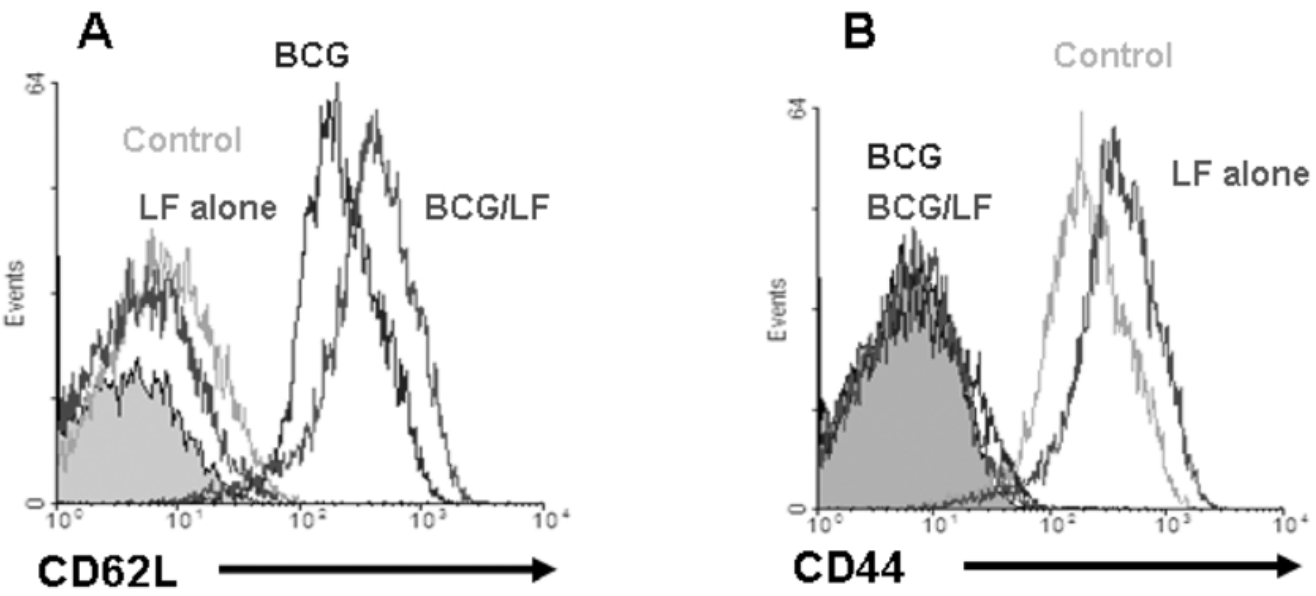

Fig. 8. BCG infected BMDCs increase CD62L and decrease CD44 when cultured with bovine lactoferrin

Bone marrow derived dendritic cells $(>90 \% \mathrm{CD} 11 \mathrm{c}+)\left(5 \times 10^{5}\right.$ cells $\left./ \mathrm{mL}\right)$ were cultured with BCG (MOI 10: 1) with or without bovine lactoferrin $(100 \mathrm{mg} / \mathrm{mL})$ or remained uninfected. After $72 \mathrm{~h}$, cells were collected and stained for expression of CD62L-FITC (A) or CD44FITC (B). 

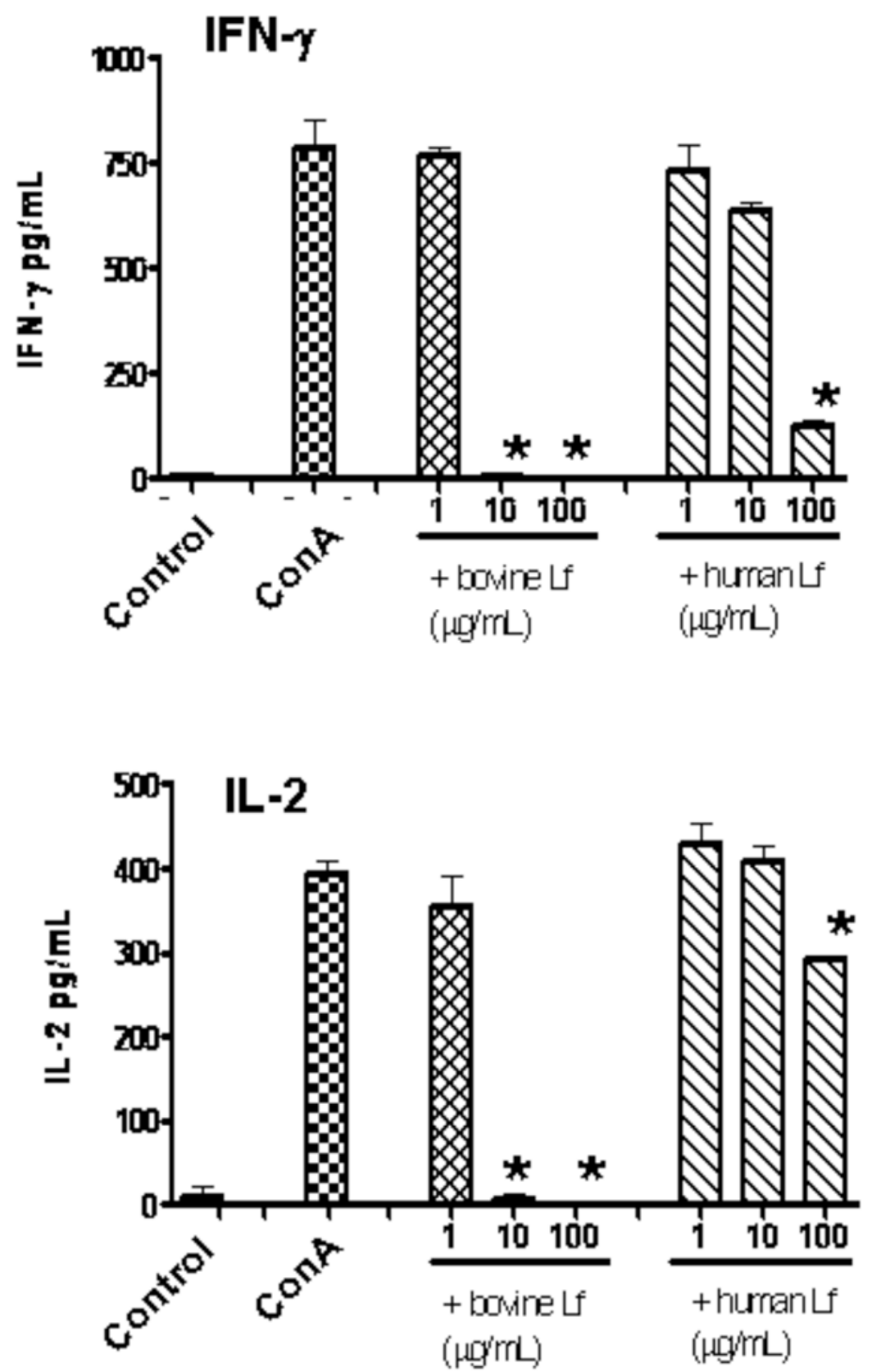

Fig. 9. Lactoferrin decreases T-cell cytokines from Con A stimulated splenocytes Non-adherent splenocytes $\left(2 \times 10^{6}\right.$ cells $\left./ \mathrm{mL}\right)$ were isolated from C57BL/6 mice. Production of IFN- $\gamma(\mathbf{A})$ and IL-2 (B) were measured by ELISA after $72 \mathrm{~h}$ stimulation with Con A (2 $\mu \mathrm{g} / \mathrm{mL})$ in the presence of increasing concentration of bovine or human lactoferrin $(1,10$, $100 \mu \mathrm{g} / \mathrm{mL}) . * p<0.05$ 


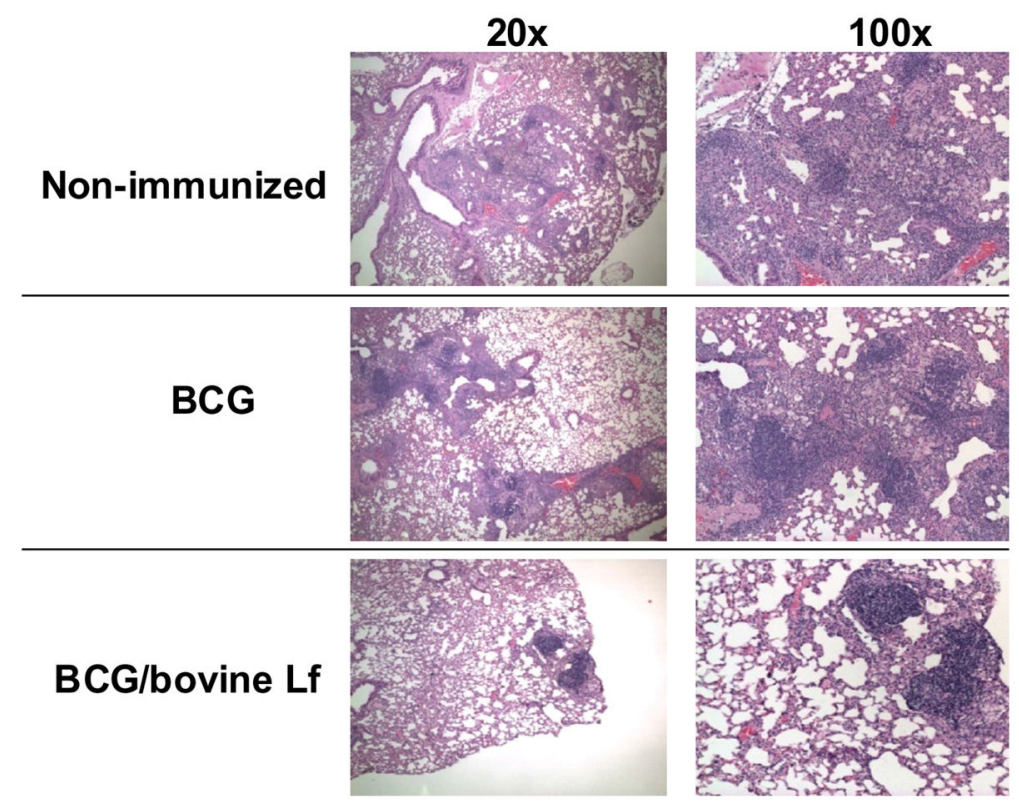

Fig. 10. Mice immunized with BCG and lactoferrin demonstrate diminished inflammation and destructive pulmonary histopathology upon challenge with virulent MTB

C57BL/6 mice (6 per group) demonstrated reduced histological manifestation of disease in the BCG/lactoferrin immunized groups at day 65 post challenge. The top panels depict histopathology from a non-immunized control and is compared to mice immunized and boosted with BCG vaccine (middle panels). The lactoferrin adjuvant immunized mice (bottom panels) revealed striking reduction in granulomas with evidence of lymphocytic clusters and contained focal pockets of inflamed monocytes. Staining with H\&E (20× or $100 \times$ magnification). 
Table 1

The Role of Lactoferrin in Moderation of Development of LPS-Induced Endotoxemia in Mice

\begin{tabular}{|c|c|c|}
\hline Biological Effect & LPS-Induced Endotoxemia & Lactoferrin Pretreatment/LPS-Induced Endotoxemia \\
\hline $\begin{array}{c}\text { Behavioral Activity } \\
\text { Body Temperature } \\
\text { Intestinal Structure }\end{array}$ & $\begin{array}{c}\text { Severely Reduced (Lethargy) } \\
\text { Severe Hyperthermia } \\
\text { Severe Injury }\end{array}$ & $\begin{array}{c}\text { Normal } \\
\text { Moderate Hyperthermia } \\
\text { Moderate Injury }\end{array}$ \\
\hline Survival & $\begin{array}{c}83.3 \% \text { Mortality } \\
\mathrm{P}<0.05\end{array}$ & $\begin{array}{c}16.7 \% \text { Mortality } \\
\mathrm{P}<0.05\end{array}$ \\
\hline Inflammatory Mediators: & & Reduction $(\mathrm{P}<0.05)$ \\
IL-6 at $2 \mathrm{~h}$ & Increase & Reduction $(\mathrm{P}<0.05)$ \\
TNF- $\alpha$ at $2 \mathrm{~h}$ & Increase & Reduction $(\mathrm{P}<0.05)$ \\
Nitric Oxide at $6 \mathrm{~h}$ and $18 \mathrm{~h}$ & Increase &
\end{tabular}


Table 2

The Sugar Content of Bovine and Human Lactoferrins

\begin{tabular}{|c|c|c|}
\hline \multirow{2}{*}{ Monosaccharide } & \multicolumn{2}{|c|}{ [\%] of the Total MW } \\
\cline { 2 - 3 } & Bovine Lactoferrin & Human Lactoferrin \\
\hline Fucose & 0.21 & - \\
\hline Galactose & 0.45 & 1.08 \\
\hline Mannose & 4.84 & 1.35 \\
\hline N-Acetylglucosamine & 4.25 & 2.48 \\
\hline N-Acetylgalactosamine & 0.85 & - \\
\hline Acetylneuraminic Acid & 0.6 & 1.0 \\
\hline Total & 11.2 & 5.9 \\
\hline
\end{tabular}

